\title{
Yield, vegetation and succession in reserved fields in Central Finland
}

\author{
Heikki Hokkanen and Mikko Raatikainen \\ University of Jyväskylä, Department of Biology \\ Vapaudenkatu 4, 40100 Jyväskylä 10 Finland
}

\begin{abstract}
Central Finland in 1974. 107 vascular plant taxa were identified, having a total oven-dry green biomass of $273.5 \mathrm{~g} / \mathrm{m}^{2}$ on the average, and a total mean biomass of $1458.1 \mathrm{~g} / \mathrm{m}^{2}$. The amount of the above-ground biomass stays about the same at least for three years after 2-3 years of increase, whereas the underground biomass increases strongly at least during the first six years, if succession starts after open cultivation. The general tendency in succession at the species level is for the typical weed species of open cultivations to reduce in a few years, and for the species of meadow vegetation to increase both in frequency and abundance.

Five vegetation types were distinguished: 1) Galeopsis-type, 2) Phleum-type, 3) Anthoxanthum-type, 4) Deschampsia-type, and 5) Elytrigia-type. They can all be placed into a certain succession scheme that is mainly determined by the age, soil and moisture conditions of the reserved field.
\end{abstract}

\section{Introduction}

Based on the Field Reservation Act (216/1969), about $8 \%$ of the cultivated area in Finland had been reserved by the end of 1974 (Anon. 1975). Research on the productivity, care and effect on the environments of the reserved fields was started in the University of Jyväskylä in 1973. Two papers have already been published on this subject (TörmäLÄl and Hokkanen 1976, TörmäLÄ and RAatikainen 1976). The purpose of this study is to identify the species composition, yield, vegetation types, and succession of vegetation in reserved fields.

The yield and flora of grasslands for hay (=leys) has been thoroughly studied in Finland (e.g. PaAtela 1953a and 1953b, RaAtikainen and RaATIKAINEN 1975), and numerous works on the flora and vegetation of different types of meadows have been published (e.g. Linkola 1916, 1921, TERÄsvuORI 1920, Kalela 1939 and Kosonen 1969). Mukula et al. (1969) have published an extensive study on the weed flora of cereal fields in Finland. Comparable studies on abandoned fields have been made in the USA, by e.g. Golley (1960, 1965), Wiegert and Evans (1964) and Mellinger and McNaughton (1975). 


\section{Material and methods}

\subsection{Study area}

The study area consisted of the following communes: Jyväskylä, the rural commune of Jyväskylä, Petäjävesi and Uurainen (about $62^{\circ} \mathrm{N}$ and $25^{\circ} \mathrm{E}$ ) in Central Finland. 20 reserved farms were selected at random, and from each $2-3$ homogenous fields again at random. Thus 51 fields were obtained, which were reserved as follows: 13 in 1969 (=6th year fields), 5 in 1970 , 6 in 1971, 11 in 1972,10 in 1973 and 6 in 1974 (=1st year fields). 23 fields had last been on hay or pasture, 10 on oat, 7 on barley, and on wheat, rye, carrot, potato and cabbage 1 each; 6 had been on unknown open cultivation. The moisture of the fields varied so that 16 were classified as dry, 27 as intermediate, and 8 as moist. 35 fields were situated on moraine or sand soils, 7 on silt or clay soils, and 6 on organic soils. 5 fields had been forested, 2 with pine, 2 with birch and 1 with spruce. Herbicides had been used only on one forested field. The reserved fields were often surrounded by forest. The area of clearing, on which the fields were located, was over 50 ha in 3 cases, $10-50$ ha in 1 case, $5-10$ ha in 8 cases, $3-5$ ha in 11 , $1-3$ ha in 19 and less than 1 ha in 9 cases.

\section{2. Sampling}

Samples were taken according to the instructions by Milner and Hughes (1968). From each field 4 points were chosen at random, and from each point a circular sample of $0.25 \mathrm{~m}^{2}$ was clipped at ground level. The samples were deep-frozen and sorted later by hand. Green parts of the vegetation were sorted according to species, except for mosses (into one group) and Agrostis, Alchemilla and Taraxacum (into genus). About $95 \%$ or more of the Agrostis were A.tenuis. Other species were A. canina, A. stolonifera, A. gigantea and Agrostis hybrids. Above-ground dead plant material (= detritus) was also treated as one group. The samples were air-dried and weighed, and the water content was determined by keeping subsamples at $85^{\circ} \mathrm{C}$ for two days. The mean water contents of the monocotyledons, dicotyledons and detritus were $5.6 \%$ (S. E. 0.1 ), $7.4 \%$ (S. E. 0.1) and $7.0 \%$ (S. E. 0.1). The difference between the mono- and dicotyledons was highly significant $\left(\mathrm{t}=13.88^{* * *}\right)$. All given biomass values have been corrected to correspond to oven-dried values.

Underground parts of the vegetation were sampled by a soil auger with an area of $150 \mathrm{~cm}^{2}$ to $20 \mathrm{~cm}$ depth, from the midpoints of the clip-plots after clipping. According to Linkola and Tirrikka (1936), more than $90 \%$ of the underground biomass can be expected to be included in the samples. The underground parts of the vegetation were separated from the soil by a sieve set (mesh sizes 10.0, 5.0 and $2.5 \mathrm{~mm}$ ) and a water jet. The samples were air-dried and weighed, the ash content was determined by keeping the subsamples in a $550^{\circ} \mathrm{C}$ oven for three days. The mean water content of the samples was $3.3 \%$ (S.E. 0.1) and the ash content $6.7 \%$ (S.E. 0.8). The underground biomasses are expressed in oven-dried weights $\mathrm{g} / \mathrm{m}^{2}$.

A total of 184 vegetation samples were cut, equalling $46 \mathrm{~m}^{2}$. From 5 fields samples could not be taken as they had been mowed earlier. Underground 
biomasses were sampled also from them so that in all 204 underground samples were taken, equalling $3.06 \mathrm{~m}^{2}$. The samples were taken on 16-24 July, 1974. According to TörmäLÄ and RAatikainen (1976), the vegetation has by that time already reached its maximum biomass, and no great changes take place for several weeks.

The nomenclature of the vascular plants is given according to LID (1974), and of the mosses according to NyHolm (1954). The following names, however, have been used in sensu lato: Chenopodium album, Chrysanthemum leucanthemum, Poa pratensis, Polygonum aviculare, Ranunculus acris, R. auricomus, Rumex acetosa, R. acetosella, and Matricaria inodora.

\subsection{Statistical calculations}

Following methods were used in the calculations:

1) $\chi^{2}$-contingency table (see Chapman 1976).

$$
\begin{aligned}
& \chi^{2}=\frac{(\mathrm{ad}-\mathrm{bc})^{2} \mathrm{n}}{(\mathrm{a}+\mathrm{b})(\mathrm{c}+\mathrm{d})(\mathrm{a}+\mathrm{c})(\mathrm{b}+\mathrm{d})}, \text { where } \\
& \mathrm{a}=\text { number of samples, where both species } 1 \text { and } 2 \text { occur } \\
& \mathrm{b}=1 \text { occurs but not } 2 \\
& \mathrm{c}= \\
& \mathrm{d}= \\
& \mathrm{n}=\text { total number of samples }
\end{aligned}
$$

The significance of the correlation is obtained from standard $\chi^{2}$-significance tables with 1 degree of freedom.

2) Sørensen's quotient of similarity

$$
\begin{aligned}
& \text { QS }=100 \times \frac{\Sigma 2 \mathrm{c}}{\Sigma(\mathrm{a}+\mathrm{b})}, \text { where } \\
& \mathrm{a}=\text { the amount of a species in sample } 1 \\
& \mathrm{~b}=\text { the amount of the same species in sample } 2 \\
& \mathrm{c}=\text { the smaller of these two values (a and } \mathrm{b})
\end{aligned}
$$

3) Shannon-Weaver -index for species diversity

$$
\begin{aligned}
& \bar{H}=-\sum\left(\frac{n_{i}}{N}\right) \log _{2}\left(\frac{n_{i}}{N}\right) \text {, where } \\
& n_{i}=\text { importance value for each species } \\
& N=\text { total of importance values }
\end{aligned}
$$

The following symbols for the levels of significance are used in all the tests: $\mathrm{p}^{*}<.05, \mathrm{p}^{* *}<.01$ and $\mathrm{p}^{* * *}<.001$. 


\section{Results}

\subsection{Species composition and yield}

Altogether 107 vascular plant taxa were identified from the samples. According to Table 1 the most abundant taxa were Phleum pratense, Agrostis spp., Elytrigia repens, Deschampsia caespitosa and Achillea millefolium, while the most frequent taxa were Agrostis spp., Phleum pratense, Achillea millefolium, Poa pratensis and Ranunculus repens. The frequency value of $\mathbf{5}$ taxa exceeded $50 \%, 14$ taxa exceeded $20 \%$ and 24 taxa $10 \%$. 14 taxa were present only in one sample. Mosses were identified in some random samples; the most abundant species were Rhytidiadelphus squarrosus and Polytrichum juniperinum, other identified species were Aulacomnium palustre, Pleurozium schreberi, Dicranum scoparium, Brachythecium praelongum, B. populeum and Sphagnum squarrosum.

The mean green biomass was $273.5 \mathrm{~g} / \mathrm{m}^{2}$, of which monocotyledons formed $195.5 \mathrm{~g} / \mathrm{m}^{2}$, dicotyledons $77.9 \mathrm{~g} / \mathrm{m}^{2}$, and mosses $0.1 \mathrm{~g} / \mathrm{m}^{2}$. Detritus amounted on the average to $130.3 \mathrm{~g} / \mathrm{m}^{2}$, bringing the total above ground plant material to $403.8 \mathrm{~g} / \mathrm{m}^{2}$. The underground biomass, however, was more than twice that of the above-ground, being $1054.3 \mathrm{~g} / \mathrm{m}^{2}$. Thus the total plant material $/ \mathrm{m}^{2}$ was on the average $1458.1 \mathrm{~g}$. The total biomass of the most important weed species - all those listed by Mukula (1964) and RaAtikainen et al. (1971) - averaged $104.2 \mathrm{~g} / \mathrm{m}^{2}$, and that of the cultivated species (Phleum pratense, Trifolium pratense, T. repens, Festuca pratensis and Lolium spp. (cf. RaATIKAINEN and RAATIKAINEN 1975) $89.6 \mathrm{~g} / \mathrm{m}^{2}$.

\section{2. Succession and the effect of environmental factors}

The effects of the age (as a reserved field) and the previous use of the fields are presented in Table 1 and Figures 1-4. In many cases there is a clear difference in the occurrence of the taxa and biomasses according to whether succession has started from open (after open cultivation) or ley (after fields for hay or pastures) vegetation. After ley the total amount of green biomass stays the same or slightly decreases (after the 3rd year $r=-0.452^{*}$ ) with time, whereas after open cultivation it first strongly increases, exceeding clearly the yield from fields after ley on the 2 nd and 3 rd year $\left(t=2.31^{*}\right)$. After this maximum the green biomasses decrease and reach about the same level as in the fields after ley (Fig. 1a). Fig. 1b shows that the described maximum is parctically totally due to the biomass increase in the monocotyledons, since the green biomass of the dicotyledons stays the same or slightly decreases with time. Independently of the previous use, the amount of detritus strongly increases with time (Fig. 1c, $\mathrm{r}=0.560^{* * *}$ ), being significantly greater after ley $\left(r=0.339^{*}\right)$, however. Above-ground biomass reaches its maximum in a few years and then stays about the same in both cases (Fig. 1d), whereas the underground biomasses grow clearly with time after open cultivations but not after ley (Fig. 1e, r=0.507***).

The proportion of monocotyledons of the green biomass remains about the same after ley, but after open cultivation it rises strongly from about $13 \%$ 
Table 1. Green biomasses $\left(\mathrm{g} / \mathrm{m}^{2}\right)$ of plant taxa in different classes. $\mathrm{O}=$ after open cultivations, $\mathrm{L}=$ after leys, $1-6=$ age classes, $\mathrm{F} \%=$ frequency $\%$ in the whole material, $\mathrm{n}=$ number of samples in each class.

\begin{tabular}{lllllllllllll}
$\mathrm{O}_{1}$ & $\mathrm{O}_{2}$ & $\mathrm{O}_{3}$ & $\mathrm{O}_{4}$ & $\mathrm{O}_{5}$ & $\mathrm{O}_{6}$ & $\mathrm{~L}_{1}$ & $\mathrm{~L}_{2}$ & $\mathrm{~L}_{3}$ & $\mathrm{~L}_{4}{ }_{5}$ & $\mathrm{~L}_{6}$ & $\begin{array}{c}\text { All } \mathrm{F} \% \\
\text { fields }\end{array}$ \\
\hline
\end{tabular}

Achillea millefolium

A. ptarmica

27.2

Alchemilla spp

Alopecurus geniculatus

A. pratensis

Angelica sylvestris

Anthoxanthum odoratum. ........

Anthriscus sylvestris .............

Barbarea vulgaris...

Belula pubescens

B. verrucosa ............................. -

Calamagrostis epigeios .......... -

Calluna vulgaris ................... -

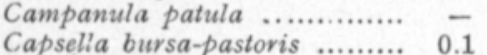

Carex canescens ................... -

C. echinata....

C. leporina ......................... -

C. nigra .......................... 0.0

C. pallescens .......................
Cerastium fontanum ............

Chamaenerion angustifolium .. -

Chenopodivm album ........... 1.4

Chrysanthemum leucanthemum 0.0

Cirsium arvense ................... 8.9

C. heterophyllum ................ -

C. palustre

Deschamsia caespitosa ...........

Elytrigia repens

$\overline{2.1}$

2.1
3.7

Epilobium palustre

0.3

Equisetum arvense

E. fluviatile

E. palustre

E. sylvaticum

Erysimum cheiranthoides ....... 0.4

Festuca pratensis ................ 0.1

F. rubra ........................... -

Filipendula ulmaria ...............
Fumaria officinalis .............

0.1

Galeopsis bifida

16.7

G. speciosa ........

0.1

G. uliginosum

0.1

G. vaillantii ........................ 0.2

Geranium sylvaticum ................ -

Geum rivale ........................ -

Gnabhalium sylvaticum ...........

G. uliginosum ...................... 0.1

Hieracium pilosella

H. umbellatum

H. vulgatum

Hypericum maculatum ...........

Juncus filiformis ..................

Juniperus communis .............

Knautia arvensis ................. -

Lapsana communis .............. 5.9

Lathyrus pratensis

-

$\begin{array}{rr}39.5 & 17.3 \\ 3.2 & 4.4 \\ 70.6 & 50.9 \\ - & 0.0 \\ - & - \\ - & - \\ 0.0 & -.1 \\ - & - \\ - & - \\ 0.5 & -\end{array}$

$\begin{array}{lll}9.0 & 4.2 & 11.7\end{array}$

$\begin{array}{ll}2.5 & 11.8\end{array}$

$\begin{array}{rrrrr}3.1 & 21.7 & 10.1 & 4.0 & 1.5\end{array}$

$\begin{array}{lllll}62.8 & 16.6 & 42.3 & 21.6 & 39.4\end{array}$

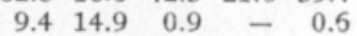

- $-1-1-$

$\begin{array}{ccccc}\overline{0.6} & \overline{0.0} & \overline{0.4} & - & -\end{array}$

$\begin{array}{llll}2.3 & 4.7 & 3.7 & -\end{array} .6 .6$

$\begin{array}{lllll}- & 2.5 & 1.3 & 6.3 & -\end{array}$

- $\quad$ - $-\quad-\quad-\quad-0.1$

$\begin{array}{cc}- & - \\ \overline{-} & - \\ 0.1 & - \\ \overline{0.0} & -\end{array}$

-

$-$

1.

1.0
7.4

0.2

0.1

0.0

$\overline{0.5} \quad 13 . \overline{2}$

- 20.

$36.2 \quad 14.9$

5.9

69.3

$\begin{array}{ll}- & \bar{c} \\ \overline{-} & - \\ \overline{0} & \overline{-} \\ \overline{-} & \mathbf{1 . 6} \\ 0.7 & - \\ 4.0 & - \\ - & -\end{array}$

0.1

1.8

0.1

$0.1 \quad 0.3$

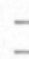

-

$=$

-1
$\overline{0}$
1.6
$\overline{-}$
$\overline{-}$

0.8

5.1

$\begin{array}{lllll}0.1 & 0.0 & 0.0 & 0.0 & 0.0\end{array}$

$\begin{array}{lllll}- & - & 0.0 & 0.0 & 0.1\end{array}$

- $\quad-\quad 0.2$

- $0.2-$

$\begin{array}{llll}- & - & - & 0.5 \\ - & - & - & -\end{array}$

-

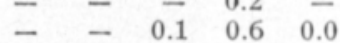

- - - - -

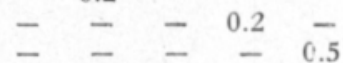

$\begin{array}{lllll}25.0 & 3.5 & 10.5 & 15.1 & 66\end{array}$

$\begin{array}{lllll}31.2 & 4.8 & 2.8 & 7.7 & 39\end{array}$

$\begin{array}{lllll}16.7 & 24.7 & 48.4 & 38.0 & 79\end{array}$

$\begin{array}{lllll}0.2 & 24.2 & 2.1 & 4.4 & 19\end{array}$

$\begin{array}{lllll}- & - & 0.1 & 0.0 & 1\end{array}$

$\begin{array}{lllll}2.5 & 0.1 & - & 0.2 & 1\end{array}$

$1.5-0.0$
-0.26

$\begin{array}{llll} & 7.4 & 0.8 & 1.6\end{array}$

- $\quad-0.00 .628$

$-\quad-0.01$

$\begin{array}{lcccc}- & 1.1 & - & 0.1 & 2 \\ - & - & \overline{-} & 0.0 & 1 \\ - & - & 0.9 & 0.1 & 1 \\ - & - & 1.8 & 0.3 & 2 \\ - & - & 0.6 & 0.6 & 9 \\ - & - & - & 0.0 & 1 \\ - & - & 0.0 & 0.6 & 3 \\ - & - & \overline{1} & 0.4 & 3 \\ - & 1.3 & 1.1 & 0.9 & 6 \\ - & - & 2.8 & 2.5 & 3\end{array}$

$-0.6-0.16$

$\begin{array}{lllll}0.2 & 0.3 & 0.2 & 0.6 & 25\end{array}$

0.8
$-\quad 0.80 .83$

$-\quad-\quad-\quad 0.14$

$-\quad-\quad-1.01$

$-\quad-\quad 2.03$

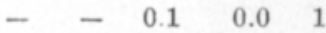

$-\quad-\quad-1.92$

$\begin{array}{lllll}51.0 & 13.5 & 30.6 & 18.2 & 31\end{array}$

$\begin{array}{lllll}42.3 & 86.4 & 29.4 & 37.0 & 30\end{array}$

$\begin{array}{rrrrr}- & - & - & 0.0 & 1 \\ - & - & 0.1 & 0.2 & 5 \\ - & - & - & 0.0 & 1 \\ - & - & 0.1 & 0.1 & 5 \\ 0.8 & 0.3 & 0.1 & 0.9 & 14 \\ - & - & - & 0.1 & 4 \\ 0.1 & 0.1 & - & 2.0 & 6 \\ 8.7 & 13.4 & 7.9 & 7.5 & 37 \\ - & - & 0.0 & 0.1 & 2 \\ - & - & - & 0.0 & 1\end{array}$

$\begin{array}{llll}0.1 & 1.6 & - & 0.214\end{array}$

$\begin{array}{llll}-\quad 5.0 & 0.1 & 2.5 & 12\end{array}$

$-\quad-\quad 0.03$

$0.4 \quad-\quad-0.17$

$\begin{aligned} & 0.4 \\ & -1\end{aligned}-0.01$

$\begin{array}{llll}0.1 & - & 2.0 & 0.3\end{array}$

$\begin{array}{llll}0.0 & -\quad 4.6 & 0.7 & 3\end{array}$

- $\quad-\quad-0.01$

$\begin{array}{cccc}-\quad & 0.2 & 0.0 & 1\end{array}$

$\begin{array}{lllll}0.4 & 0.0 & 1.0 & 0.5 & 4\end{array}$

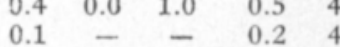

$\begin{array}{llllllllll}1.6 & 0.9 & - & - & 0.0 & - & 1.5 & - & 0.3 & 4 \\ 3.3 & - & 5.0 & 5.8 & - & - & - & 1.1 & 1.1 & 3\end{array}$

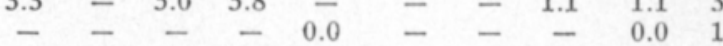

- $7.0-1-0$ - - - 0.61

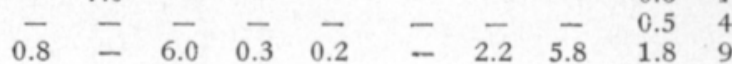




$$
\begin{array}{llllllllllll}
\mathrm{O}_{1} & \mathrm{O}_{2} & \mathrm{O}_{3} & \mathrm{O}_{4} & \mathrm{O}_{5} & \mathrm{O}_{6} & \mathrm{~L}_{1} & \mathrm{~L}_{2} & \mathrm{~L}_{3} & \mathrm{~L}_{4}{ }^{-5} & \mathrm{~L}_{6} & \underset{\text { fields }}{\mathrm{Alll}} \mathrm{F} \%
\end{array}
$$

Leontodon autumnalis ..............................

Linaria vulgaris

Lolium perenne .................. -

Luzula multiflora ................. -

L. pallescens .......................

$\begin{array}{lrr}\text { Matricaria inodora } & \ldots \ldots \ldots \ldots \ldots . . . & 17.7 \\ \text { Myosotis arvensis ................. } 0.9\end{array}$

Phleum pratense

Pinus sylvestris

Plantago major

Poa annua

$P$. pratensis

$P$. trivialis

Polygonum aviculare 0.1

$P$. convolvulus .................... 0.0

P. lapathifolium ................... -

$P$. viviparum ...................... 0.0

Potentilla erecta ..................... -

P. norvegica ........................ -

Prunella vulgaris ................ 0.0

Ranunculus acris ................ 0.0

$R$. auricomus

R. repens

6.5

Rhinanthus minor. ............... -

Rumex acetosa .....................

$R$. acetosella ..................... -

Rubus arcticus .....................

$R$. saxatilis ....................... -

Silene vulgaris .................... -

Sonchus arvensis ................. 13.7

Spergula arvensis ................ 1.9

Stellaria graminea ............... 0.1

S. media

1.3

Trifolium pratense ................ 0.7

$T$. repens

1.7

$T$. spadiceum ........................
Taraxacum spp. .................

Tussilago farfara ................ -

Vaccinium myrtillus .............. -

$V$. officinalis ......................

V. serpyllifolia

$$
0.7
$$

Vicia cracca ....................... 0.0

$V$. hirsuta ......................... -

$V$. sepium .......................... -

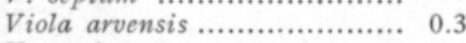

$V$. canina

$V$. palustris

$V$, riviniana

Musci

Lichenes $\begin{array}{ll}0.3 & 0.0\end{array}$

$0.0-3.2 \quad 1.6$

$\begin{array}{lll}-\quad 0.4 & 0.2\end{array}$

1.018

$5.0-$

$0.1 \quad 0.0$

$\begin{array}{lllr}\overline{0} & - & - & - \\ 0.0 & - & - & 0.2\end{array}$

$-\quad 0.0$

$0.0-0.0$

$-\quad 0.0$

$-\quad 0.2$

$-2$

$0.1 \quad 0.1 \quad 0.1$

$\begin{array}{llll}- & - & 1.4 & 0.0\end{array}$

$-\quad-$ $-\quad-0.0$

$\begin{array}{rr}02.5 & 176.7 \\ - & -\end{array}$

$0.7 \quad-$

0.0

10.0

$-$

08.258 .2

$\begin{array}{lllll} & 23.9 & 90.6 & 99.4 & 107.4\end{array}$

$$
\begin{array}{llll}
- & - & - & 0.0
\end{array}
$$

107.4

$\begin{array}{lll}-4 & -\overline{8} & -\end{array}$

$\begin{array}{llll}- & 0.1 & 0.3 & 0.1\end{array}$

$\overline{-} \quad \overline{2} \quad \overline{\overline{2}} \quad \overline{\mathrm{c}}$ -

- -

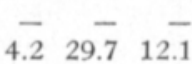

$0.3 \quad 1.6$$$
\text { - }
$$

$-\quad 0$

- 0

- 0.2

0.8

$-\quad 0.1$

0.5

1.1

2.4

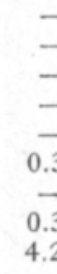

5.8

23.0

$0,0 \quad-$

$0.1 \quad 7.4$

-

- 0.1

- $\quad-$

- 4.5

$0.1 \quad-$

5

15.7
17.4

$17.4 \quad 2.8$

$\overline{1.8} \quad 0.6$

8.3

0.1

$\overline{0}$

0.1

$$
-\quad 5.5
$$

$-\quad 5.5$

$\begin{array}{ll}- & - \\ - & 0.0\end{array}$

0.1

$0.1 \quad-$

$\begin{array}{rrrrrrrrrr}3.2 & 2.5 & 1.2 & 0.9 & 5.3 & 2.0 & 0.9 & 1.4 & 4.8 & 53 \\ 0.5 & - & - & - & - & - & 0.1 & - & 0.1 & 4 \\ 0.7 & 0.0 & 0.1 & 0.0 & 1.1 & 0.3 & 0.5 & 0.1 & 0.3 & 13 \\ 2.1 & 0.2 & 1.6 & - & 0.1 & 2.3 & 0.0 & 0.3 & 1.2 & 17 \\ - & - & - & - & 0.5 & - & - & - & 0.1 & 2 \\ - & - & - & - & - & - & - & - & 0.0 & 1 \\ - & - & - & - & 3.0 & - & - & - & 0.4 & 1 \\ - & - & 0.0 & 6.1 & - & 0.5 & - & - & 1.9 & 9 \\ - & - & - & - & - & - & - & - & 0.2 & 4 \\ - & 0.6 & - & - & 0.5 & - & - & 0.1 & 0.1 & 3\end{array}$

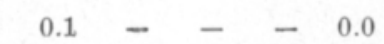

.0

$\overrightarrow{0}-\overline{0}-$

$\begin{array}{ll}0.1 & 4\end{array}$

$\begin{array}{lllll}- & - & 0.5 & 25.0 & 9.2\end{array}$

$\begin{array}{lllll}0.0 & 1.7 & 14.8 & 2.8 & 2.3\end{array}$

$\begin{array}{lll}0.1 & - & 0.8 \\ 0.3 & 0.0 & 1.7\end{array}$

$3.9 \quad 15$

- $-\quad-\quad-0.0$

$\begin{array}{lllll}21.0 & 23.9 & 8.9 & 0.9 & 3.1\end{array}$

$\begin{array}{ccc}\overline{1.6} & 5.2 & 8.6\end{array}$

$4.0 \quad 29$

$\begin{array}{ll}0.0 & 1\end{array}$

$\begin{array}{lr}0.0 & 1 \\ 6.7 & 43\end{array}$

$0.7 \quad 2$

$\begin{array}{llllllllll}\overline{-} & \overline{-} & \overline{-} & \overline{-} & 0.1 & - & \overline{1} & \overline{-} & 0.0 & 1 \\ 1.5 & 2.5 & - & 1.4 & - & - & 3.7 & 0.2 & 0.7 & 6\end{array}$

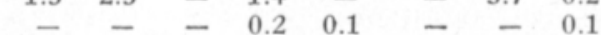

$\begin{array}{ll}0.0 & 4\end{array}$

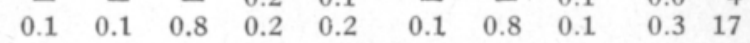

$\begin{array}{llllllllll}2.3 & 2.8 & 1.0 & 1.2 & 0.6 & 2.0 & 7.2 & 5.9 & 2.8 & 19\end{array}$

$\overline{2}-1 \quad-\quad-0.1-$

$\overline{0} \overline{3} \quad \overline{1} \quad-$

0.01

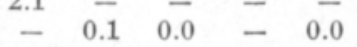

$\begin{array}{llll}-\overline{0} & - & - & -\end{array}$

$-\quad-0.1$

$-1-$

0.34

0.06

0.01

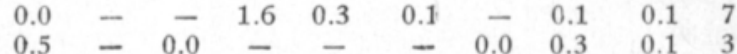

$\begin{array}{rrrrrrrrrrrr}0.0 & - & 0.3 & 0.6 & 1.3 & 0.7 & 0.6 & - & 0.0 & 1.9 & 0.6 & 17 \\ - & - & - & - & - & - & 0.0 & - & - & - & 0.0 & 1\end{array}$ 


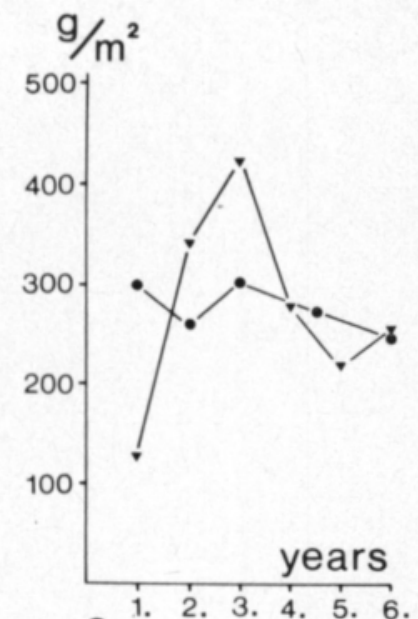

a

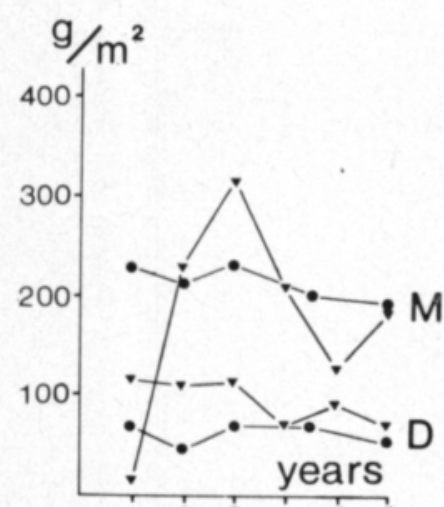

b i. 2. 3. 4. 5. 6 .
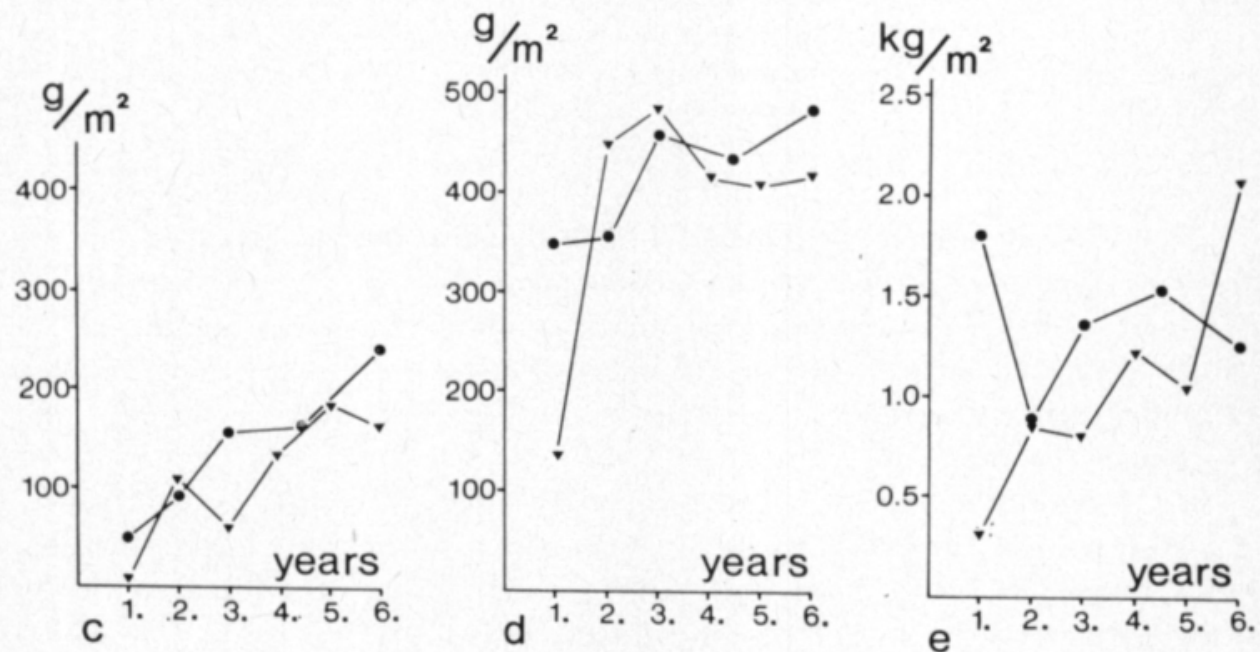

Figure 1. Plant biomasses according to age (1st-6th year reserved fields) and previous use of fields ( $\boldsymbol{\nabla}=$ after open cultivations, $\boldsymbol{\theta}=$ after leys). a) green biomasses b) green biomasses of the monocotyledons (M) and dicotyledons (D) c) detritus d) total above-ground plant mass and e) underground plant mass.

in the 1st year to about $60-70 \%$ in the following years (Fig. 2). Fig. 3 shows that the proportion of cultivated plant species decreases steadily in the first few years after ley, levelling to about $20 \%$ of the total green biomass. After open cultivation the proportion first rises, reaches the maximum during the 2nd, 3rd and 4th years, and then drops to some $20 \%$.

The amount of weeds is about the same through the years, but significant changes take place within the group after the first year following open cultivation. In the first year the proportion of annual weeds is $60 \%$ of the green weed biomass, it then drops rapidly and stays at about $5 \%$ for some two years levelling to about $1-2 \%$ later. After ley the proportion of annual weeds is about $5 \%$ of the weed biomass during the first year, decreasing to $1-2 \%$ in the 2 nd and the following years. 


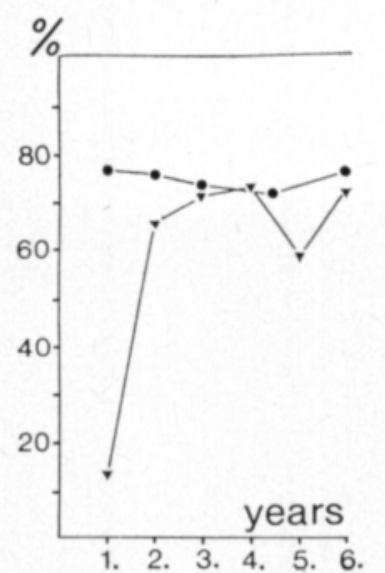

Figure 2. Proportion of the monocotyledons of green plant biomass according to age and previous use of the fields. Other data in Fig. 1.

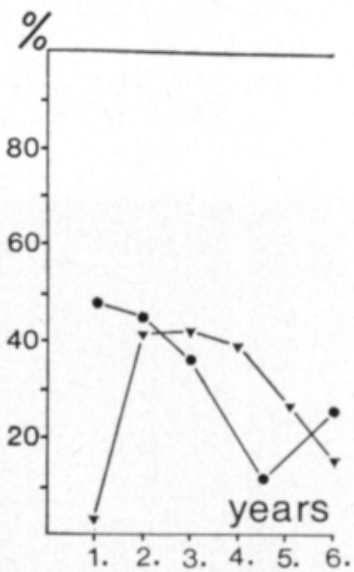

Figure 3. Proportion of cultivated species of green plant biomass according to age and previous use of the fields. Other data in Fig. 1.

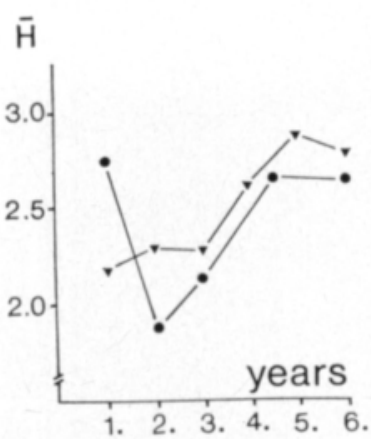

Figure 4. Species diversity as a function of age and previous use of the fields. Other data in Fig. 1.

A significant decrease with years in the biomass was observed e.g. in the following species: Spergula arvensis, Matricaria inodora, Chenopodium album, Festuca pratensis, Sonchus arvensis, amd Galium uliginosum. Significant increases appeared e.g. in the biomasses of Taraxacum spp., Anthoxanthum odoratum, Festuca rubra, Poa pratensis, Carex leporina, Calluna vulgaris, and Campanula patula (Table 1).

Fig. 4 shows the values of species diversity indices according to year-classes and previous use, calculated from the green biomasses for each field. Diversity seems to increase with years both after ley and open cultivation, but only in the latter case is the increase significant $\left(\mathrm{r}=0.447^{*}\right)$.

The effect of previous use on the abundance of species was most marked in the first growing season when significant differences occurred in the abundance of Agrostis spp., Trifolium pratense, Festuca rubra, Phleum pratense, Deschampsia caespitosa and Poa pratensis. They were all more abundant after ley. During the strong biomass-maximum (2nd and 3rd years), Ranunculus repens, Galeopsis bifida, G. speciosa and Cerastium fontanum showed a significantly greater abundance after open cultivations than after leys, subsequently (4th-6th year fields) only the abundance of Taraxacum spp. was significantly dependent on previous use; it was more abundant after open cultivations.

Moisture conditions determined to a significant degree the abundance of many species: Angelica sylvestris, Deschampsia caespitosa, Carex nigra, Galium uliginosum, Equisetum palustre and Potentilla norvegica occurred most abundantly on moist fields, whereas Taraxacum spp., Alchemilla spp., Anthoxanthum odoratum, Calluna vulgaris and Hypericum maculatum occurred on the drier fields.

The coarseness and humus content of the soil also had a significant effect on the abundance of some species. Angelica sylvestris occurred most abun- 
dantly on coarse mineral soil, Rumex acetosa, Agrostis spp., Geum rivale, and Geranium sylvaticum on fine mineral soil, and Carex nigra, Equisetum palustre, Deschampsia caespitosa, Juncus filiformis, Carex echinata, Potentilla norvegica, Poa pratensis, and Galium uliginosum occurred most abundantly on peat soils.

\subsection{Interspecies relations and vegetation types}

The $\chi^{2}$-contingency table method and the Sørensen's quotient of similarity method using the green biomasses of each species were used to detect patterns in vegetation. Five different community types were recognized (Figs. 5 and 6):

1) Galeopsis speciosa-type (Table 2, Figs. 5 and 6). The characteristic species are Galeopsis speciosa, Sonchus arvensis, Spergula arvensis, Stellaria media, Matricaria inodora, etc. The type is heterogenous (see Fig. 6) and it is possibly divisible into two or more subtypes, e.g. according to the dominance

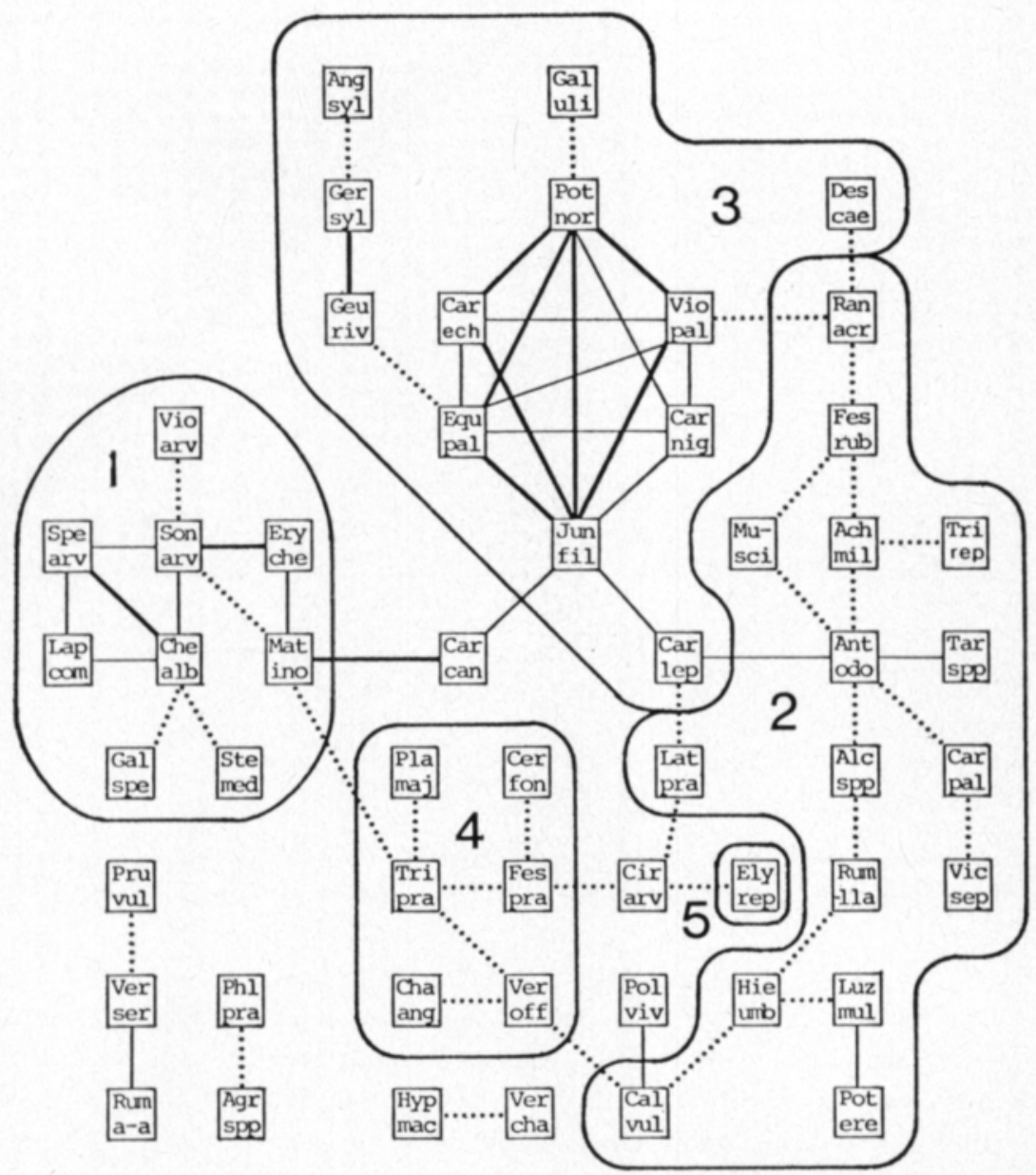

Figure 5. $\chi^{2}$-correlation between species. Straight lınes: heavy $=\mathrm{p}<0.001$, narrow $=\mathrm{p}<0.01$, dotted $=\mathrm{p}<0.05$. Curved lines show the boundaries of vegetation types. 1) Galeopsis-type 2) Anthoxanthum-type 3) Deschampsiatype 4) Phleum-type 5) Elytrigia-type. 


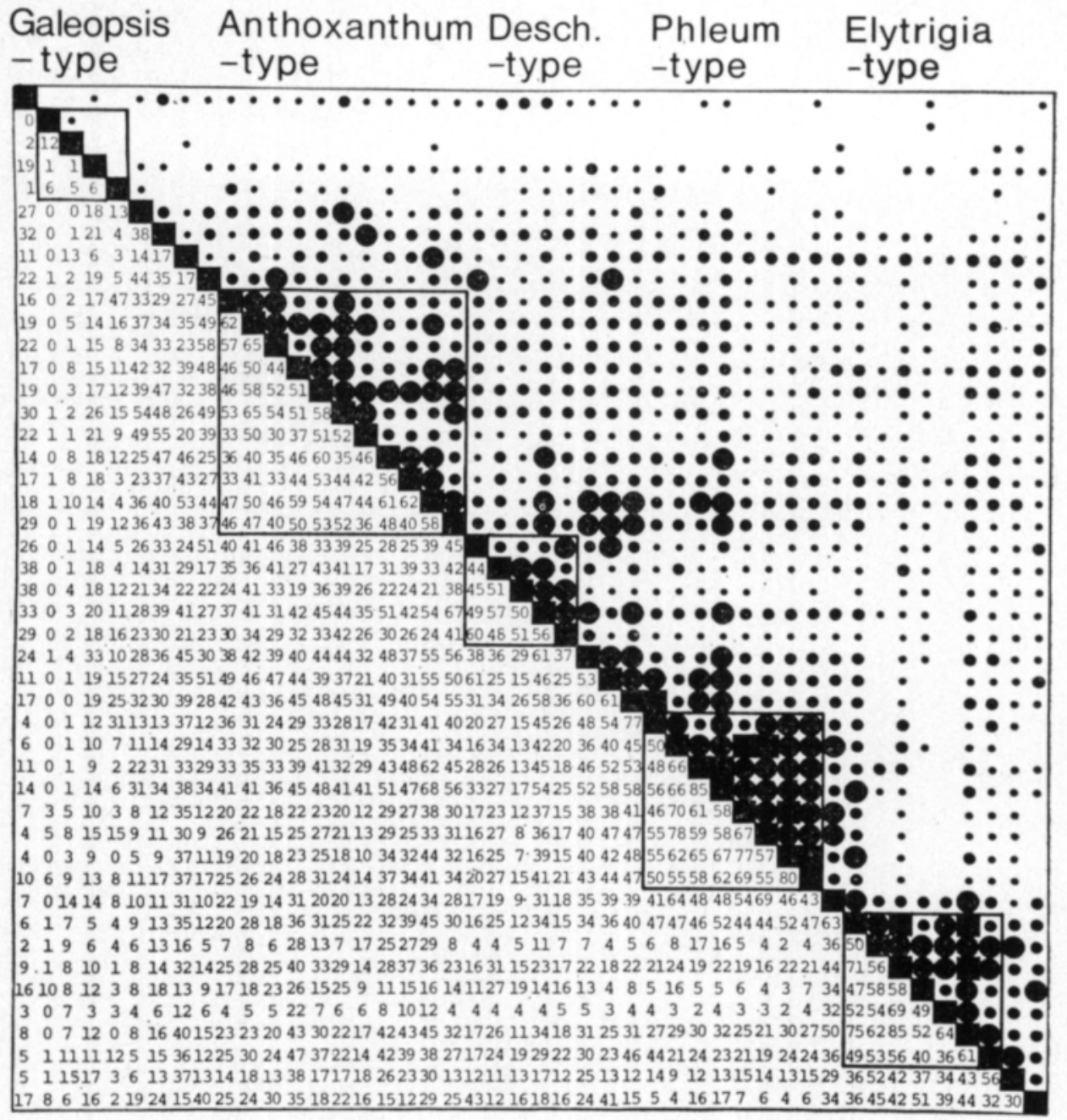

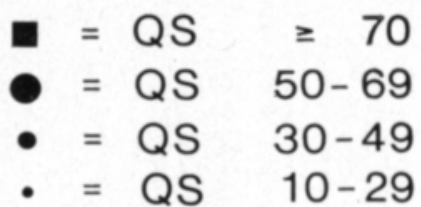

Figure 6. Similarity between sample areas according to Sørensen's quotient of similarity (US), and the representative areas in each vegetation type distinguished with this method.

of various species, at present the available data is not sufficient, however. The type is fairly species-poor and the biomass is small. The proportion of dicotyledons was the highest of the described types. Stands of this type occur usually on mineral and sometimes organic soils after open cultivation.

2) Anthoxanthum odoratum-type (Table 2, Figs. 5 and 6). The characteristic species are Agrostis tenuis, Achillea millefolium, Taraxacum spp., Anthoxanthum odoratum and Festuca rubra. This is a fairly species-rich type of mainly older and drier fields than the average, mainly on coarse mineral soils, which have 
Table 2. The constancy and biomass of species in community types. $\mathrm{C}=$ constancy- $\%$ in $0.25 \mathrm{~m}^{2}$ sample areas, $\mathrm{B}=$ green biomass $\mathrm{g} / \mathrm{m}^{2}$.

\begin{tabular}{|c|c|c|c|c|c|c|c|c|c|c|}
\hline & \multicolumn{3}{|c|}{ Guleopsis A nihoxanthum } & B & \multicolumn{2}{|c|}{$\begin{array}{l}\text { Deschampsia } \\
\text {-type }\end{array}$} & $\begin{array}{l}\text { Phleum } \\
\text {-type } \\
\text { C \% }\end{array}$ & \multicolumn{3}{|c|}{$\begin{array}{l}\text { Elytrigia } \\
\text {-type }\end{array}$} \\
\hline Galeopsis speciosa ............... & 50 & 16.6 & 5 & 0.1 & 5 & 0.5 & 13 & 0.9 & 15 & 2.9 \\
\hline Sonchus arvensis ................ & $5 C$ & 13.8 & - & - & 5 & 0.0 & 13 & 3.8 & 7 & 0.3 \\
\hline Spergula arvensis ................ & 50 & 1.9 & - & - & - & - & - & - & - & - \\
\hline Stellaria media .................... & 50 & 1.4 & 2 & 0.0 & - & - & - & - & 4 & 6.0 \\
\hline Matricaria inodora .............. & 38 & 11.5 & - & - & - & - & 6 & 0.6 & - & - \\
\hline Chenopodium album ............. & 38 & 1.4 & - & - & - & - & - & - & - & - \\
\hline Lapsana communis ............... & 31 & 5.9 & - & - & - & - & 6 & 0.1 & - & - \\
\hline Veronica serpyllifolia ........... & 31 & 0.7 & 11 & 0.3 & 15 & 0.1 & 13 & 0.1 & 19 & 0.4 \\
\hline Viola arvensis ....................... & 25 & 03 & 7 & 0.1 & 5 & 0.1 & 3 & 0.0 & 4 & 0.0 \\
\hline Leontodon autumnalis ........... & 25 & 0.3 & 14 & 0.3 & 20 & 1.c & 16 & 1.0 & 7 & 0.2 \\
\hline Galeopsis bifida ................... & 25 & 0.2 & 5 & 0.0 & - & - & 22 & 0.1 & 19 & 1.0 \\
\hline Erysimum cheiranthoides ...... & 19 & 0.4 & - & - & - & - & 6 & 0.0 & 4 & 0.0 \\
\hline Polygonum aviculare ............. & 19 & 0.3 & - & - & - & - & - & - & - & - \\
\hline Galium uliginosum .............. & 19 & 6.1 & 2 & 0.0 & 5 & $0 . \mathrm{C}$ & 6 & C.1 & - & - \\
\hline Cirsium arvense ................... & 13 & 8.9 & 2 & 0.2 & - & - & 3 & 0.0 & - & - \\
\hline Myosotis arvensis ................ & 13 & 0.9 & - & - & - & - & - & - & - & - \\
\hline Equisetum arvense ................ & 13 & 0.9 & 7 & 0.4 & 5 & 0.1 & - & - & 7 & 0.2 \\
\hline Galium vaillantii ................. & 13 & 0.2 & - & - & - & - & - & - & - & - \\
\hline Galium palustre .................. & 13 & 0.1 & - & - & - & - & 3 & 0.0 & - & - \\
\hline Fumaria officinalis ............. & 13 & 0.0 & - & - & - & - & - & - & - & - \\
\hline Gnaphalium uliginosum ......... & 6 & 0.1 & 2 & 0.1 & - & - & - & - & - & - \\
\hline Capsella bursa-pastoris .......... & 6 & 0.1 & - & - & - & - & - & - & - & - \\
\hline Polygonum viviparum ........... & 6 & 0.0 & 2 & 0.0 & - & - & - & - & - & - \\
\hline Polygonum convolvulus ........... & 6 & 0.0 & - & - & - & - & 3 & 0.0 & - & -.. \\
\hline Chrysanthemum leucanthemum & 6 & 0.0 & - & - & - & - & 3 & 0.0 & - & - \\
\hline Agrostis spp. ..................... & 19 & 2.7 & 98 & 56.3 & 75 & 52.3 & 78 & 20.8 & 59 & 4.7 \\
\hline Achillea millefolium .............. & 25 & 27.4 & 95 & 245 & 75 & 11.3 & 63 & 14.4 & 41 & 2.7 \\
\hline Tararacum spp. .................. & 13 & 0.4 & 70 & 12.0 & 35 & 2.9 & 47 & 10.9 & 56 & 7.3 \\
\hline Anthoxanthum odoratum ....... & - & - & 66 & 4.9 & 20 & 0.1 & 16 & 0.4 & 26 & 1.6 \\
\hline Festuca rubra ..................... & - & - & 57 & 18.6 & 65 & 7.3 & 13 & 1.1 & 37 & 7.6 \\
\hline Ranunculus acris ................ & 6 & 0.0 & 34 & 2.6 & 25 & 0.9 & 6 & 0.3 & 19 & 0.5 \\
\hline Alchemilla spp. ................... & - & - & 32 & 8.9 & 10 & 11 & 16 & 1.9 & 19 & 0.4 \\
\hline 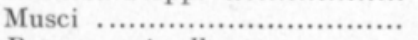 & - & - & 32 & 0.8 & 20 & 2.1 & 6 & 0.1 & 4 & 0.0 \\
\hline Rumex acetosella ................. & - & - & 23 & 1.0 & 20 & 1.8 & 13 & 0.3 & 11 & 0.3 \\
\hline Lathyrus pratensis .............. & - & - & 16 & 4.7 & 10 & 4.5 & 13 & 0.8 & - & - \\
\hline Anthriscus sylvestris ............ & - & - & 16 & 1.2 & - & - & 3 & 1.6 & 4 & 3.1 \\
\hline Rhinanthus minor ................ & - & - & 16 & 0.2 & - & - & - & - & - & - \\
\hline Vicia sepium ..................... & - & - & 14 & 1.2 & - & - & 3 & 0.2 & - & - \\
\hline Veronica chamaediys ............ & - & - & 14 & 6.8 & - & - & 6 & 1.1 & - & - \\
\hline Carex pallescens ................. & - & - & 14 & 0.3 & - & - & - & - & - & - \\
\hline Prunella vulgaris ................. & 6 & 0.0 & 14 & 0.2 & 10 & 0.6 & 6 & 0.1 & 4 & C.C \\
\hline Hieracium umbellatum .......... & - & - & 11 & 1.4 & 5 & 0.1 & - & - & - & - \\
\hline Calluna vulgaris .................. & - & - & 9 & 0.3 & - & - & - & - & - & - \\
\hline Hypericum maculatum ......... & - & - & 7 & 0.8 & - & - & 3 & 0.0 & - & - \\
\hline Luzula pallescens ................ & - & - & 7 & 0.1 & 5 & 0.1 & 3 & 0.0 & - & - \\
\hline Linaria vulgaris ................... & - & - & 5 & 0.6 & - & - & - & - & - & - \\
\hline Knautia arvensis ................ & - & - & 2 & 1.9 & - & - & - & - & - & - \\
\hline Hieracium pilosella .............. & - & - & 2 & 0.2 & - & - & - & - & - & - \\
\hline Alopecurus geniculatus ........... & - & - & 2 & 0.0 & - & - & - & - & - & - \\
\hline Deschampsia caespitosa ......... & 25 & 2.1 & 16 & 4.7 & 90 & 120.0 & 25 & 0.5 & 4 & 3.5 \\
\hline Poa pratensis ..................... & 31 & 1.5 & 75 & 14.0 & 75 & 14.2 & 59 & 7.5 & 67 & 16.6 \\
\hline Achillea ptarmica ................. & 25 & 6.5 & 45 & 6.8 & 65 & 10.1 & 25 & 7.8 & 22 & 7.8 \\
\hline Ranunculus repens ................ & 44 & 6.6 & 57 & 2.9 & 65 & 1.8 & 53 & 4.6 & 26 & 0.5 \\
\hline Viola palustris .................... & - & - & 2 & C. 0 & 35 & 0.7 & - & - & - & - \\
\hline Vicia cracca ....................... & 6 & 0.0 & 27 & 2.7 & 30 & $\mathbf{3 4 . 2}$ & 22 & 4.1 & 19 & 0.7 \\
\hline Trifolium repens ................. & 31 & 1.7 & 25 & 2.9 & 30 & 2.4 & 31 & 1.8 & 15 & 0.8 \\
\hline Angelica sylvestris ................ & - & - & 5 & 0.0 & 25 & 1.3 & - & - & 7 & 0.2 \\
\hline Juncus filiformis ................ & - & - & 2 & 1.2 & 20 & 5.5 & - & - & - & - \\
\hline Potentilla norvegica .............. & - & - & - & - & 20 & 0.4 & - & - & - & - \\
\hline Carex canescens .................... & 6 & 0.0 & - & - & 15 & 4.0 & 3 & 0.0 & - & - \\
\hline Equisetum palustre ............... & 13 & 0.3 & - & - & 15 & 0.4 & - & - & - & - \\
\hline
\end{tabular}




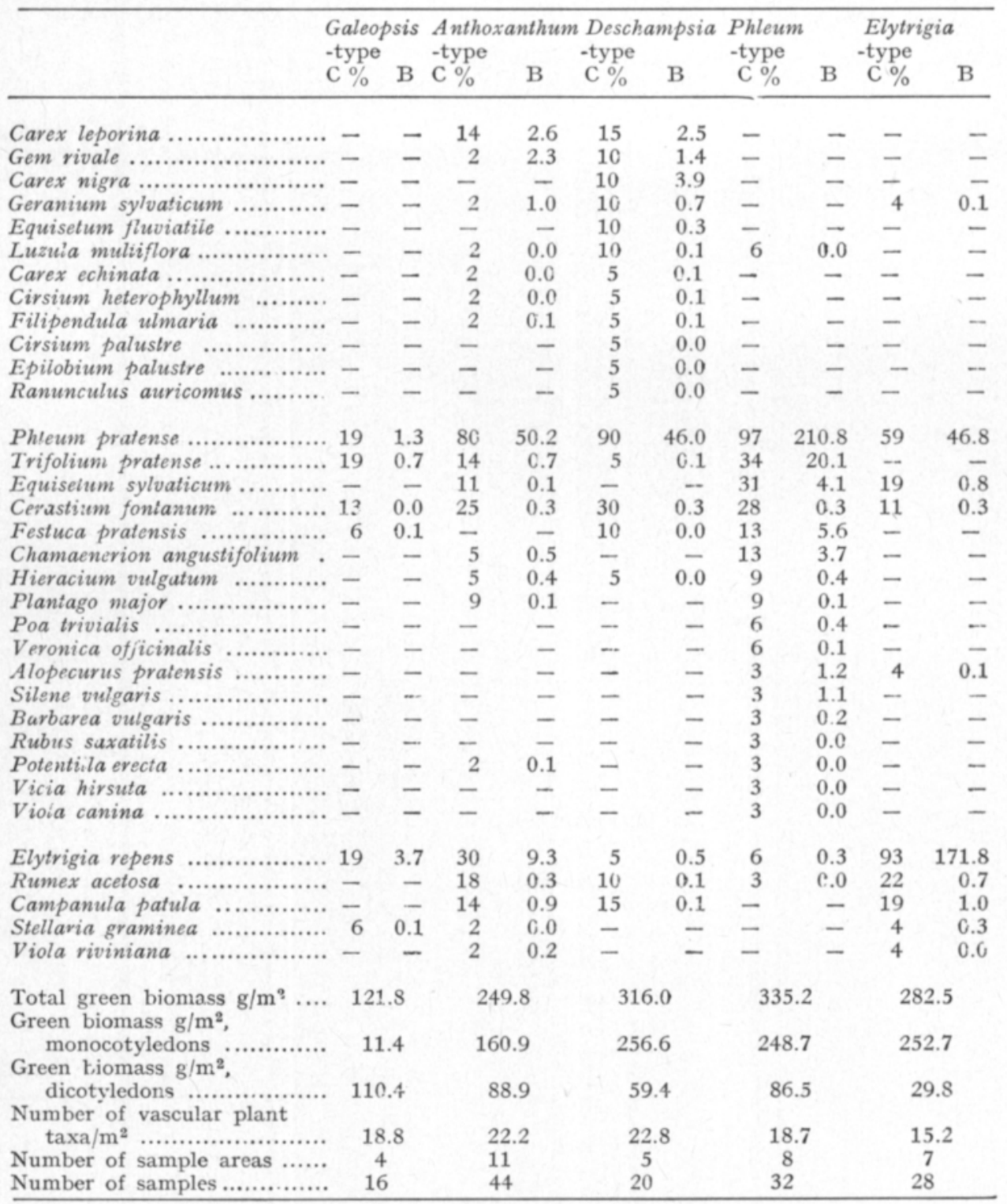


most often been reserved after open cultivation. The proportion of dicotyledons was high, $36 \%$ of the green biomass.

3) Deschampsia caespitosa-type (Table 2, Figs. 5 and 6). The characteristic species are e.g. Deschampsia caespitosa, Achillea ptarmica, Viola palustris, and Juncus filiformis. This is a species-rich type, growing on clearly moister and older fields than the average, most often on organic soils. The total green biomass in this type exceeds clearly that of the previous types, owing entirely to the greater biomass of the monocotyledons.

4) Phleum pratense-type (Table 2, Figs. 5 and 6). The characteristic species are Phleum pratense, Trifolium pratense, Equisetum sylvaticum, Festuca pratensis and Chamaenerion angustifolium. This is a fairly species-poor type with the greatest total green biomass, which is mainly due to Phleum pratense with $210.8 \mathrm{~g} / \mathrm{m}^{2}$. The amount of cultivated plants is $69 \%$ of the total green biomass, which shows that this type occurs mainly on young fields that have most often been reserved after ley.

5) Elytrigia repens-type (Table 2, Figs. 5 and 6). Elytrigia repens is a clear monodominant in this type, forming $61 \%$ of the total green biomass. This type is very poor in species, and dicotyledons form only $11 \%$ of the total green biomass. It occurs on all kinds of fields, most often on those reserved after ley.

These communities can all be ranged into a certain habitat or successional stage. Fig. 7 outlines the succession on reserved fields according to the previous use and moisture conditions of the field. After open cultivations, annual weed communities (Galeopsis-type) prosper during the first growing season, and are soon replaced by Anthoxanthum-, Deschampsia-, or Phleum-communities according to the moisture conditions. After leys, the Phleum-type usually dominates, but this usually changes to the Anthoxanthum-type in mineral soil or the Deschampsia-type in organic soil after 1-4 years. The Elytrigia-type can form in any field where Elytrigia has previously been abundantly present. The boundaries between the different types are sometimes quite diffuse, and the effect of the previous use of the field disappears after some years and the vegetation changes into the individual plant type that is typical of each habitat.

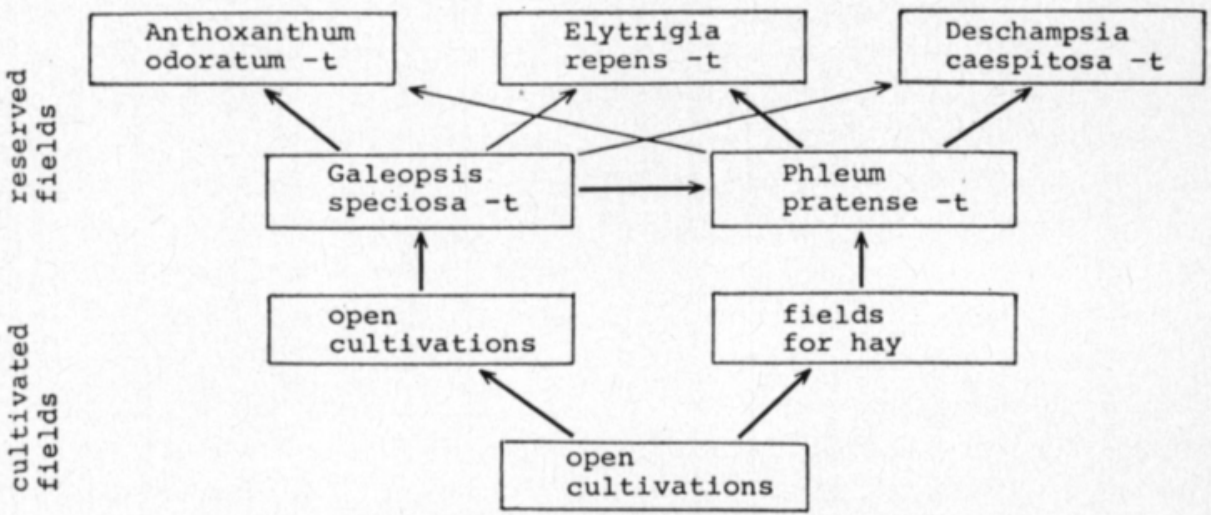

Figure 7. Succession of plant communities in reserved fields. The left sides of the boxes represent the drier ends, the right sides the wetter ends of the types. The widths of the arrows indicate the most probable directions. 


\section{Discussion}

\subsection{Species composition and yield}

According to RaAtikainen and RaAtikainen (1975), the average yield from leys in Central Finland is $354,7 \mathrm{~g} / \mathrm{m}^{2}$ (air-dried wt, $9 \%$ water content). TERÄSVUORI (1920) gives some average yields from natural meadows in NcrthSavo at the beginning of this century: best waterlogged areas $250-300(-400)$ $\mathrm{g} / \mathrm{m}^{2}$, good Deschampsia-meadows $200-250(-300) \mathrm{g} / \mathrm{m}^{2}$, and RanunculusChrysanthemum leucanthemum-meadows $100-200 \mathrm{~g} / \mathrm{m}^{2}$. The average yield from meadows in 1908-1912 was about $320 \mathrm{~g} / \mathrm{m}^{2}$. All Teräsvuori's figures are air-dry weights and the water content may be about $10-20 \%$ (not given). In Tvärminne, Southern Finland, Kosonen (1969) found that the maximum standing crop biomass on a dry coastal meadow varied from 300 to $650 \mathrm{~g} / \mathrm{m}^{2}$ (air-dry wt). In Poland, the maximum biomass on two different types of meadows varied between $476-585 \mathrm{~g} / \mathrm{m}^{2}$ (TRACZYK 1971), and from the USA e.g. the following standing-crop figures for abandoned fields are given: $251-385$ $\mathrm{g} / \mathrm{m}^{2}$ (Michigan, Golley 1960), 283-494 g/m² (South Carolina, Odum 1960), $165-283 \mathrm{~g} / \mathrm{m}^{2}$ (SE-Michigan, WIEgert and Evans 1964). The average yield from reserved fields in Central Finland $\left(273.5 \mathrm{~g} / \mathrm{m}^{2}\right.$, oven-dried wt) corresponds well with the yields from our best natural meadows, as well as with the figures for abandoned fields from the USA, while it is clearly less than the yield from leys or from more southernly meadows.

The floristical similarity between reserved fields and leys is evident if one compares the lists of the most abundant species: the 4 most abundant species on the reserved fields are also among the $\mathbf{5}$ most abundant species in leys (cf. RaAtikainen and RaAtrkainen 1975). Trifolium pratense, the second in abundance in leys, was only 12 th in reserved fields. Distinct differences occurred in the biomass-relations of the species, however: Phleum was not so dominant in reserved fields as in leys, and it reduced earlier than in leys; the differences in abundance of the other species were likewise clearer in reserved field3. According to RaAtikainen and RaAtikainen (1975), the average proportion of cultivated species in leys was $74 \%$, in reserved fields the figure was $33 \%$, on the average. The proportions decreased with years, however, so that in 5 th year leys it was only $41 \%$ and in reserved fields $20 \%$.

The biomass of weeds in reserved fields (104.2 $\mathrm{g} / \mathrm{m}^{2}$ oven-dry wt) does not differ significantly from that in cereal fields $\left(78-134 \mathrm{~g} / \mathrm{m}^{2}\right.$, air-dry wt, MuKULA 1974). There is a significant difference in species composition, however. The only abundant species on reserved fields was Elytrigia repens, whose biomass formed over one third of the total weed biomass. It averaged $37.0 \mathrm{~g} / \mathrm{m}^{2}$ in reserved fields, 16.6 in cereal fields (Mukula 1974), and $15.3 \mathrm{~g} / \mathrm{m}^{2}$ in leys (RAatikainen and RAatikaInen 1975). The occurrence of Elytrigia on reserved fields was very uneven: it appeared on relatively few fields, but was usually then very abundant (the frequency-\% of Elytrigia was 30, while the Elytrigia-type occupied $15 \%$ of all fields). According to Mukula et al. (1969), the most typical weeds in the cereal fields of the study area are some perennial weeds (Deschampsia caespitosa, Ranunculus repens, Leontodon autumnalis and Rumex spp.), and some species typical of Southern Finland (e.g. Tussilago 
farfara and Sonchus arvensis). The green biomasses of those species were in leys (RAatikainen and RaAtikainen 1975)/reserved fields 13.7/18.2, 6.1/4.8, $0.9 / 1.0,2.4 / 1.5,0.2 / 0.7$ and $0.4 / 1.9 \mathrm{~g} / \mathrm{m}^{2}$, respectively. In this respect also reserved fields resemble leys very closely.

\subsection{Interspecies relations and vegetation types}

Two methods were used to distinguish the five communities. Both method; give essentially the same results, since species groups in Fig. 5 correspond very well with the list of typical species for each type in Table 2. Figs. 5 and 6 show also the relations between different types, and that the boundaries between them are often quite diffuse. For example, according both to Fig. 5 and Table 2, Carex leporina could be easily classified as either an Anthoxanthum-type or a Deschampsia-type-species.

Of the communities described, the Deschampsia-type corresponds well with the Deschampsia caespitosa - Rumex acetosa-type described by RAATIKAINEN and RAATIKAINEN (1964) from edges of fields; Rumex is, however, clearly less represented in the type from reserved fields. This may be partly due to the differeaces in the geographical distribution of Rumex. Both studies confirm that this type occurs mainly on organic soils. Our Phleumtype corresponds best with the Phleum pratense - Trifolium repens-type of RaAtikainen and RaAtikainen (1964). On reserved fields Trifolium pratense occurs instead of $T$. repens, due partly to different location, soil types, etc; in this respect our Phleum-type resembles more leys than that of RaAtikarnen and RaAtikainen (1964). The communities on reserved fields greatly resemble those described by TERÄSvUORI (1920) from natural or semi-cultivated meadcws in North-Savo, especially his Aireta caespitosae and Ranunculeta meadows. Our Deschampsia-type corresponds well with his "proper Aira-meadows", and for most of the variants of this type that he describes, a correspondent can also be found on the reserved fields. In fact, several of the meadows that Teräsvuori studied had once been at least semi-cultivated. For all other communities from reserved fields a correspondent can be found on semicultivated meadows, except for our Elytrigia-type. The nature of the Elytrigiatype makes it questionable whether it can be classified as an independent

association at all. Because of the extreme species-poverty, and the lack of such communities in natural meadows, this type could probably be better defined as a facies of an association. However, the Elytrigia-type is of great practical importance when reserved fields are again cleared for cultivation.

\section{3. Succession}

Decrease in net productivity with time has been established, apart from this work, also in leys (PAatela 1953a, RaAtikainen and RaAtikainen 1975) and abandoned fields in the USA (Mellinger and McNaughton 1975). MelLINGER and MCNAUGHTON (1975) noticed that the species diversity increased in long term succession; this could be detected already during the first years of succession in reserved fields. TERÄSVUORI (1920) noted the effect of previous use of the area on the flora and vegetation of the meadow, and that the 
differences disappeared after a few years, as they also do in reserved fields. Compared with his results, succession proceeds in abandoned fields practically in the same manner as in reserved fields. RAATIKAINEN and RAatikainen (1975) present information about succession in leys. Species that occur most abundantly in first year leys are weed species of open cultivations, in 1-2 year leys they are perennially cultivated species, and species that are most abundant in 2-4 year leys are perennial weeds. Species that prosper in older leys are usually species that grow in closed meadow vegetation.

As causes of succession on abandoned fields KEEVER (1950) suggests: 1) different life cycles of species and 2) different responses to environmental factors. During the first year species whichaad germinated already in the previous autumn or early in the spring, spread and grow fast, and the vegetation usually becomes temporarily closed during the first year. Subsequently several other factors start to determine the outlines of succession. According to PaAtela and ERviö (1971), there are about 44000 seeds $/ \mathrm{m}^{2}$ in the soil of Finnish fields, and from these the vegetation quickly develops during the first growing season. At that time nutrients are generally abundantly available and so the biomass increases rapidly. After the 3rd year the nutrient content has become reduced (e.g. tied up into detritus and underground parts, whose biomasses increase with time), and the green biomasses have to decrease accordingly. At that time competition between species is directed especially to nutrients and light, which later mainly determine the development of the vegetation in the field. According to Linkola (1935), the competition of the roots is the main factor regulating the growth, development and occurrence of plant species in meadows. This explains also the great gradual increase of the underground biomass in reserved fields.

TERÄSVUORI (1920) states that the basic reason for different meadow types and vegetation zones is the difference in moisture conditions. Regarding the long-term succession, he concludes that all wet and probably also moist meadows will, in the long run, turn swampy, the most important moss-species being some Polytrichum and Sphagnum species. The same development may also take place in relatively dry meadows, if the vegetation becomes open for some reason (grazing, cloven-foot traces, etc), and the mosses obtain space where to start and spread. Even the oldest reserved fields in Finland are relatively young meadows so that the spreading of the mosses could not conclusively be detected. However, some fields did show a tendency towards such a development.

Acknowledgements. We are grateful to Mr. Timo Törmälä, M. Sc., who took part in the field and laboratory work. The financial support from the National Research Council for Sciences is greatly appreciated. 


\section{REFERENCES}

AnoN. 1975. Monthly review of agricultural statistics 1: 1-56.

Chapman, S. B. 1976. Methods in plant ecology. 536 p. London.

Golley, F. B. 1960. Energy dynamics of a food chain of an old field community. Ecol. Monogr. 30, 2: 187-206.

- - 1965. Structure and function of an old field broomsedge community. Ecol. Monogr. 35: $113-131$.

Kalela, A. 1939. Uber Wiesen und wiesenartige Pflanzengesellschaften auf der Fischerhalbinsel in Petsamo Lappland. Acta Forest. Fenn. 48, 2: 1-523.

Kenver, C. 1950. Causes of succession on old fields of the Piedmont, North Carolina. Ecol. Monogr. 20, 3: 229-250.

Kosonen, M. 1969. Primary production, composition and seasonal growth rhythm of some dry meadow communities on the south coast of Finland. Comm. Biol. 31, 4: 1-23.

LID, J. 1974. Norsk og svensk flora. 808 p. Oslo.

LrNkolı, K. 1916. Studien über den Einfluss der Kultur auf die Flora in den Gägenden nördlich vom Ladogasee I. Acta Soc. F. Fl. Fenn. 45, 1: I-VII + 1-429.

- - 1921. Studien über den Einfluss der Kultur auf die Flora in den Gägenden nördlich vom Ladogasee II. Acta Soc. F. Fl. Fenn. 45, 2: 1-491.

- - 1935. Uber die Dauer und Jahresklassenverhältnisse des Jugendstadiums bei einigen Wiesenstauden. Acta Forest. Fenn. 42, 2: 1-56.

_ - _ \& TIrikкA, A. 1936. Uber Wurzelsysteme und Wurzelausbreitung der Wiesenpflanzen auf verschiedenen Wiesenstandorten. Ann. Bot. Soc. 'Vanamo' 6, 6: I-VII + 1-207.

Mellinger, M. V. \& McNaughton, S. J. 1975. Structure and function of successional vascular plant communities in central New York. Ecol. Monogr. 45: 161-182.

Milner, C. \& Hughes, R. E. 1968. Methods for the measurement of the primary production of grassland. IBP handbook 6. 70 p. Berkshire.

Mukula, J. 1964. Rikkaruohot ja niiden torjunta. 140 p. Helsinki.

- 1974. Weed competition in spring cereal fields in Finland. Forskn. Förs. Lantbr. 25: $585-592$.

- - , RaAtikainen, M., Lallukka, R. \& RaAtikainen, T. 1969. Composition of weed flora in spring cereals in Finland. Ann. Agric. Fenn. 8: 59-110.

Nyноцм, E. 1954. Illustrated moss flora of Fennoscandia II: 1-6. Musci. 799 p. Lund.

ODum, E. P. 1960. Organic production and turnover in old field succession. Ecology 41: $34-49$.

PaAtela, J. 1953 a. Eri ikäisten peltonurmien osuudesta, käytöstä, pintalannoituksesta ja heinåsadoista Suomessa. Summary: On the utilization, fertilizing, and yields of hay of rotation leys in Finland with special reference to the age of ley. Acta Agr. Fenn. 79, 2: $1-60$.

- 1953 b. Maamme heinänurmien botaanisesta koostumuksesta. Summary: On the botanical composition of the tame-hayfields in Finland. Acta Agr. Fenn. 79, 3: 1-128.

- - \& Erviö, L-R. 1971. Weed seeds in cultivated soils in Finland. Ann. Agric. Fenn. 10: $144-152$.

RaAtikainen, M. \& RaAtikarnen, T. 1964. Kevätviljapeltojen ja niiden pientareiden kasveista Laihialla. Summary: Plant species growing on spring cereal fields and their edges at Laihia, Finland. J. Scient. Agric. Soc. Finl. 36: 135-160.

_- - \& RAatikannen, T. 1975. Heinänurmien sato, kasvilajikoostumus ja sen muutokset. Summary: Yield, composition and dynamics of flora in grasslands for hay in Finland. Ann. Agric. Fenn. 14:57-191.

- - - RaAtikainen, T. \& Trnnil Ā, A. 1971. Rikkakasvit ja niiden torjunta. Kasvinsuojeluseur. Julk. 46: 1-108.

TERĀsvuori, K. 1920. Muistiinpanoja Pohjois-Savon "Luonnonniityistä». Referat: Aufzeichnungen über die snaturlichen Wiesens in Nord-Savo. J. Scient. Agric. Soc. Finl. 4: 1181.

TraczYK, T. 1971. Productivity investigation of two types of meadows in the Vistula valley. I. Geobotanical description and primary production. Ekol. Pol. 19: 93-106. 
TörmäLĀ, T. \& Ноккаnen, H. 1976. Pakettipeltojen ja niiden reuna-alueiden linnustosta Keski-Suomessa. Keski-Suomen Linnut 1:44-47.

- - \& RaAtikainen, M. 1976. Primary production and seasonal dynamics of the flora and fauna of the field stratum in a reserved field in Middle Finland. J. Scient. $\Lambda$ gric. Soc. Finl. 48: 363-385.

Wiegert, R. G. \& Evans, F. C. 1964. Primary production and the disappearance of dead material on an old field in south-eastern Michigan. Ecology 45: 49-63.

Ms received May 9th, 1977.

\title{
SELOSTUS
}

\section{Pakettipeltojen sato, kasvillisuus ja sen mutokset Keski-Suomessa}

\author{
Heikкi Hokкanen ja Mrkкo RaAtrkainen \\ Jyväskylän yliopisto, Biologian laitos
}

Tutkimuksen tarkoituksena on selvittää mitä pellon käytön rajoittamisesta annetun lain piiriin kuuluvalla normaalisti hoidetulla ns. pakettipellolla kasvaa ja miten kasvillisuus muuttuu paketointiaikana. Työssä pyritään selvittämäån miten pellon käytőn rajoittamisesta annettuja säädöksiä on noudatettu rikkakasvittumisen osalta ja mitä tulee ottaa huomioon, kun paketoituja peltoja otetaan viljeltäviksi.

Tutkimuskohteina oli 20 tilan 51 peltolohkoa, jotka poimittiin otannalla Jyväskylästä ja sen ympäristökunnista. Kultakin lohkolta leikattiin sato heinäkuussä 1974 neljältä $0.25 \mathrm{~m}^{2}: \mathrm{n}$ suuruiselta alalta ja joka alan keskustasta otettiin $150 \mathrm{~cm}^{2}$ :n suuruinen näyte kasvien maanalaisista osista.

Näytteissä oli 107 putkilokasvilajia. Maanpäällinen vihreä sato oli keskimäärin $2735 \mathrm{~kg} / \mathrm{ha}$ ja koko kasvimateriaalin määrä oli $14581 \mathrm{~kg} / \mathrm{ha}$. Avoviljelysten jälkeen paketoiduilla pelloilla maanpäällisen kasvimassan määrä kasvoi voimakkaasti noin kahden-kolmen ensimmäisen vuoden aikana, mutta pysytteli sen jälkeen suunnilleen samana ainakin kolme vuotta. Maanalaisen kasvimassan määrä kasvoi jatkuvasti ainakin kuuden ensimmäisen vuoden ajan. Nurmen tai laitumen jälkeen paketoiduilla pelloilla kasvimassan määrässä ei tapahtunut muita merkittäviä muutoksia kuin karikkeen määrän selvä kasvu vähintään kuuden ensimmäisen vuoden ajan.

Kasvilajistossa iän mukana tapahtuvista muutoksista merkittävimpiä olivat avoviljelysten tyypillisten rikkakasvilajien ja viljeltyjen lajien väheneminen sekä vanhojen nurmien kasvillisuudessa ja niittykasvillisuudessa esiintyvien lajien runsastuminen.

Pakettipelloilta kuvattiin viisi kasvustotyyppiä. Avoviljelysten jälkeen ensimmäisenä kesånä vallitsivat pilliketyypin kasvustot, jotka hyvin pian muuttuivat lähinnä kosteus- ja maaperäolojen mukaisesti joko simake-, nurmilauha- tai timoteityypin kasvustoiksi. Nurmen jälkeen oli useimmiten timoteityypin kasvustoja. Nämä tavallisesti muuttuivat noin $1-4$ vuodessa kuivahkoilla kivennäismailla simaketyypiksi ja kosteilla eloperäisillä mailla nurmilauhatyypiksi. Pelloilla, joissa aiemmin oli runsaasti juolavehnää, muodostui juolavehnätyypin kasvillisuutta.

Tulokset osoittavat, että pellonvarauslain alaisten viljelysten haitallinen vesottuminen on estetty tällä tutkimusalueella. Rikkakasvittumisestakaan ei ollut suurta haittaa ympäristön viljelyksille. Viljelemättä olleita aloja viljelykseen otettaessa tulee rikkakasvintorjunta keskittää juolavehnăkasvustoihin. 


\begin{tabular}{|c|c|c|c|c|c|c|c|c|c|c|c|c|c|c|c|c|c|c|c|c|c|c|c|c|}
\hline \multirow{3}{*}{$\begin{array}{l}\text { Koe- } \\
\text { ala } \\
\text { Plot } \\
\text { No. }\end{array}$} & \multirow[b]{3}{*}{$\begin{array}{l}\text { Maaalaji } \\
\text { Soil type }\end{array}$} & \multirow{3}{*}{\multicolumn{2}{|c|}{ 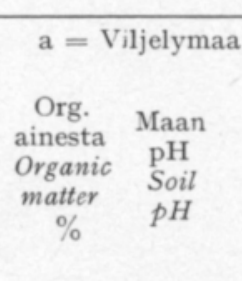 }} & \multirow{2}{*}{\multicolumn{2}{|c|}{$\begin{array}{l}\text {-Cultivated soil; } \mathrm{b}=\mathrm{M} \\
\text { Vililelymaa } \\
\text { Cultivated } \\
\text { Soil }\end{array}$}} & \multirow{2}{*}{\multicolumn{2}{|c|}{$\begin{array}{l}\text { etsämaa - F Forest soil } \\
\text { Metsämaa } \\
\text { Forest soil } \\
\end{array}$}} & \multirow{2}{*}{\multicolumn{2}{|c|}{$\begin{array}{l}\text { Salaatti } \\
\text { Lettuce }\end{array}$}} & \multirow{2}{*}{\multicolumn{2}{|c|}{$\begin{array}{l}\text { Pinaatti } \\
\text { Spinach }\end{array}$}} & \multirow{2}{*}{\multicolumn{2}{|c|}{$\begin{array}{l}\text { Porkkana } \\
\text { Carrot }\end{array}$}} & \multirow{2}{*}{\multicolumn{2}{|c|}{$\begin{array}{c}\text { Puolukka } \\
\text { Lingonberries }\end{array}$}} & \multirow{2}{*}{\multicolumn{2}{|c|}{$\begin{array}{c}\text { Mustikka } \\
\text { Bineberries }\end{array}$}} & \multirow{2}{*}{\multicolumn{2}{|c|}{$\begin{array}{c}\text { Sienet } \\
\text { Mustrooms }\end{array}$}} & \multirow{2}{*}{\multicolumn{2}{|c|}{$\begin{array}{l}\text { Laidunruoho } \\
\text { Ley Grass }\end{array}$}} & \multirow{3}{*}{$\begin{array}{l}\text { Etäisyys } \\
\text { saastelähteestä } \\
\text { Distance from } \\
\text { polluting source } \\
\text { km }\end{array}$} & \multirow{3}{*}{\multicolumn{2}{|c|}{$\begin{array}{l}\text { Maalajit } \\
\text { Soil types }\end{array}$}} \\
\hline & & & & & & & & & & & & & & & & & & & & & & & & \\
\hline & & & & $\overline{\bar{x}}$ & $\begin{array}{c}\text { Luotett.- } \\
\text { rajat } \\
\text { Range } \\
(95 \%)\end{array}$ & $\overline{\overline{\mathbf{x}}}$ & $\begin{array}{l}\text { Luotett.- } \\
\text { rajat } \\
\text { Range } \\
(95 \%)\end{array}$ & $\overline{\overline{\mathbf{x}}}$ & $\begin{array}{l}\text { Luotett.- } \\
\text { rajat } \\
\text { Range } \\
(95 \%)\end{array}$ & $\overline{\overline{\mathbf{x}}}$ & $\begin{array}{c}\text { Luotett.. } \\
\text { rajat. } \\
\text { Range } \\
(95 \%)\end{array}$ & $\overline{\overline{\mathbf{x}}}$ & $\begin{array}{c}\text { Luotett. } \\
\text { rajat. } \\
\text { Range } \\
(95 \%) \\
(95 \%)\end{array}$ & $\overline{\bar{x}}$ & $\begin{array}{c}\text { Luotette. } \\
\text { rajate } \\
\text { Range } \\
(95 \%)\end{array}$ & $\overline{\bar{x}}$ & $\begin{array}{l}\text { Luotettt.- } \\
\text { rajat. } \\
\text { Range } \\
(95 \%)\end{array}$ & $\overline{\bar{x}}$ & $\begin{array}{l}\text { Luotett. } \\
\text { rajat } \\
\text { Range } \\
(95 \%)\end{array}$ & $\overline{\mathrm{x}}$ & $\begin{array}{c}\text { Luotett.- } \\
\text { rajat } \\
\text { Range } \\
(95 \%)\end{array}$ & & & \\
\hline 1 & a $\mathrm{K}$ & 4.14 & 5.9 & 28.4 & $(16.7-40.0)$ & & & 1.90 & $(1.50-2.5)$ & 1.26 & $(0.09-2.42)$ & .35 & $(0.29-0.40)$ & & 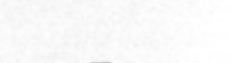 & 10 & $(0.07 \quad 012)$ & 25 & (1) & 1.91 & $(1.87-1.95)$ & & & \\
\hline 2 & $\begin{array}{l}\text { b Ht Mr } \\
\text { a Ht Mr }\end{array}$ & $\begin{array}{r}9.71 \\
3.72 \\
18.64\end{array}$ & $\begin{array}{l}3.7 \\
4.6 \\
32\end{array}$ & 583.7 & $(447.9-719.4)$ & $\begin{array}{r}61.9 \\
10362\end{array}$ & $\begin{array}{r}(4.62-198.3) \\
(7168-1355.5)\end{array}$ & 198.75 & $(27.48-424.93)$ & $52.60-$ & $-(-)$ & 12.75 & $(9.10-16.30)$ & & $127=$ & .10 & $(0.07-0.12)$ & .25 & $(0.18-0.31)$ & 2.29 & $(1.88-2.70)$ & 0.2 & & \\
\hline 3 & $\begin{array}{l}\text { b Ht Mr } \\
\text { a HHt }\end{array}$ & $\begin{array}{l}18.29 \\
4.29\end{array}$ & $\begin{array}{l}3.2 \\
4.2 \\
30\end{array}$ & 44.8 & $(15.7-73.7)$ & 1036.2 & & 22.28 & $(4.69-51.21)$ & 6.56 & $(-)$ & 5.25 & $(1.59-8.91)$ & 13.96 & $(3.75-24.17)$ & 2.02 & $(1.65-2.39)$ & 76.48 & $(6.62-159.0)$ & 3.96 & $(3.55-4.37)$ & $\begin{array}{l}0.3 \\
0.2\end{array}$ & $\begin{array}{l}\mathrm{SMMr} \\
\mathrm{HkMr}\end{array}$ & $\begin{aligned} & =\text { Gravel mor } \\
\mathrm{r} & =\text { Sand mora }\end{aligned}$ \\
\hline 4 & b ht $-\mathrm{Mm}$ & $\stackrel{21.02}{2}$ & $\stackrel{3.2}{-}$ & $\begin{array}{l}23.3 \\
36.3\end{array}$ & $(20.9-\quad 25.6)$ & 25.7 & $(4.4-41.8)$ & 3.99 & ${ }_{1050}^{(-)}$ & $\begin{array}{c}1.84 \\
1.84\end{array}$ & $(1-)^{(-)}$ & .51 & $(.44-.57)$ & 1.51 & $(0.18-2.83)$ & .54 & $-(.48-.60)$ & 53.27 & $\frac{(38.4-145.0)}{-}$ & & - & $\begin{array}{l}0.2 \\
0.8\end{array}-2$ & $\begin{array}{l}\mathrm{HthMr} \\
\mathrm{Hs} M \mathrm{Mr}\end{array}$ & $\begin{array}{l}=\text { Fines } \\
=\text { Silt }\end{array}$ \\
\hline & $=$ & $=$ & $\overline{6.5}$ & $\begin{array}{r}56.3 \\
54.5 \\
8.9\end{array}$ & 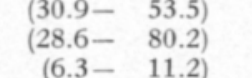 & & & $\begin{array}{l}3.08 \\
2.49 \\
65\end{array}$ & $\begin{array}{l}(2.59-3.57) \\
(1.82-3.16) \\
(0.20-1.34)\end{array}$ & $\begin{array}{l}2.92 \\
1.47 \\
1116\end{array}$ & $\begin{array}{l}(2.122-3.72) \\
0.91-2.02)\end{array}$ & $\begin{array}{l}.98 \\
.63 \\
41\end{array}$ & $\begin{array}{l}(0.04-2.00) \\
(0.16-1.10)\end{array}$ & & $\bar{z}$ & & $\bar{z}+x+3+$ & & $\Xi$ & & $\bar{z}$ & $\begin{array}{l}1.7 \\
2.8\end{array}$ & $\begin{array}{l}\text { Sr } \\
\text { KHk }\end{array}$ & $\begin{array}{l}=\text { Gravel } \\
=\text { Coarse sand }\end{array}$ \\
\hline & 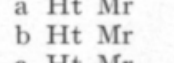 & $\begin{array}{l}8.26 \\
7.77\end{array}$ & 4.0 & 8.5 & & 7.0 & $(5.6-8.3)$ & & & & $(0.36-1.96)$ & .41 & $(.11-.71)$ & .11 & $(.11)$ & .07 & $(-)$ & 1.41 & $(0.59-2.23)$ & 1.00 & $(0.43-1.57)$ & $\begin{array}{l}\text { Tausta-alue } \\
\text { Background area }\end{array}$ & $\begin{array}{l}\mathrm{HHk} \\
\mathrm{KHt}\end{array}$ & $\begin{array}{l}=\begin{array}{l}=\text { Sand } \\
\text { and } \mathrm{Ht}\end{array}=\text { Finesand }\end{array}$ \\
\hline & $\begin{array}{l}\text { a Ht Mr } \\
\text { b Ht Mrr }\end{array}$ & $\begin{array}{l}8.37 \\
6.52\end{array}$ & $\begin{array}{l}5.3 \\
3.9\end{array}$ & 8.5 & $(3.8-13.0)$ & 4.6 & $(3.9-\quad 5.2)$ & 1.07 & $(0.64-1.48)$ & .75 & $(0.40-1.10)$ & .46 & $(.20-.72)$ & .24 & $(.10-.38)$ & .42 & $(.07-.91)$ & .80 & $(0.13-1.47)$ & 1.31 & $\stackrel{(0.69-3.31)}{-}$ & : & $\begin{array}{l}\mathrm{HHt} \\
\mathrm{Hs}\end{array}$ & $\begin{array}{l}=\text { Finer } \\
=\text { Silt }\end{array}$ \\
\hline${ }_{11}^{10}$ & a $\mathrm{HHt}$ & $\overrightarrow{3.85}$ & $\overrightarrow{5.4}$ & $\begin{array}{r}8.7 \\
39.6\end{array}$ & 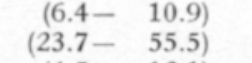 & & & $\begin{array}{l}2.49 \\
1.31 \\
-131\end{array}$ & $\begin{array}{l}\left(1.84-\quad \begin{array}{l}3.14) \\
(0.23-\end{array}\right. \\
(.38)\end{array}$ & $\begin{array}{l}1.02 \\
2.49\end{array}$ & $\begin{array}{c}(0.69-1.35) \\
(-)\end{array}$ & .64 .64 & $(0.07-1.21)$ & & $\bar{z}+x+x-1$ & & $\bar{z}+x+x+2$ & & $\overline{-}$ & & & i.o & $\begin{array}{l}\mathrm{Mm} \\
\mathrm{SMr}\end{array}$ & $\begin{array}{l}=\text { Mould soil } \\
=\text { Clay moraine soil }\end{array}$ \\
\hline 12 & $\begin{array}{l}\text { a Ht Mr } \\
\text { b Kh }\end{array}$ & $\begin{array}{l}12.27 \\
33.65\end{array}$ & $\begin{array}{l}4.4 \\
3.1\end{array}$ & 10.7 & $(4.5-12.1)$ & 24.6 & $(16.4-32.7)$ & 1.00 & $(0.70-1.30)$ & 1.47 & $(1.39-1.55)$ & .31 & $(.17-.44)$ & .14 & $(.10-.18)$ & .11 & $(.10-.11)$ & .23 & & 1.82 & $(1.53-2.10)$ & $\begin{array}{l}10.0 \\
10.0\end{array}$ & 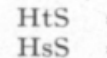 & $\begin{array}{l}=\text { Finesand clay } \\
=\text { Silt clay }\end{array}$ \\
\hline 13 & $\begin{array}{l}\text { a s Hs } \\
\text { b LCt }\end{array}$ & $\begin{aligned} 3.88 \\
65.25\end{aligned}$ & $\begin{array}{l}5.5 \\
2.8\end{array}$ & 16.2 & $(5.1-27.4)$ & 621 & $(20.4-103.7)$ & 1.15 & $(0.78-1.52)$ & 1.06 & $(0.28-1.34)$ & .42 & $(.24-.59)$ & .55 & $(0.07-1.22)$ & $(18$ & $.05-30$ & 2.29 & $(1.66-6.24)$ & .53 & $(.50-.55)$ & $\begin{array}{l}20.0 \\
200\end{array}$ & $\mathrm{LjS}$ & $\begin{array}{l}=\text { Mud clay } \\
=\text { Morhumus }\end{array}$ \\
\hline $\begin{array}{l}14 \\
16\end{array}$ & $\begin{array}{l}\text { a ht Hs } \\
\text { a KHt }\end{array}$ & $\begin{array}{l}4.66 \\
5.28\end{array}$ & $\begin{array}{l}5.4 \\
6.5\end{array}$ & $\begin{array}{r}8.2 \\
187.1\end{array}$ & $\begin{array}{l}(6.4-9.99) \\
(148.1-226.9)\end{array}$ & & & $\begin{array}{l}1.13 \\
6.29\end{array}$ & $\begin{array}{l}(0.75-1.50) \\
(4.83-\end{array}$ & $\begin{array}{l}1.23 \\
3.65\end{array}$ & $\left.\begin{array}{l}(0.37-2.09) \\
(2.04-5.16)\end{array}\right)$ & .80 & $\left(\begin{array}{l}(0.18-1.41) \\
(0.26-1.03)\end{array}\right.$ & & & & & & & .44 & $(.32-.56)$ & $\begin{array}{l}30.0 \\
30\end{array}$ & $\begin{array}{l}\mathrm{LC} \\
\mathrm{LCt}\end{array}$ & $\begin{array}{l}\text { Ligno Carex peat } \\
=\text { figesurve }\end{array}$ \\
\hline 17 & $\begin{array}{l}\text { b Ht Mrr } \\
\text { a KHt }\end{array}$ & $\begin{array}{l}6.83 \\
4.24\end{array}$ & $\begin{array}{l}3.2 \\
5.7\end{array}$ & 9.5 & $(0.9-11.7)$ & 48.4 & $(3.4-93.2)$ & 1.20 & $(0.66-1.75)$ & $1.68(\mathrm{~s})$ & $(1.53-1.82)$ & .30 & $(.09-.51)$ & .25 & $(.14-.35)$ & 1.30 & $(1.29-1.30)$ & 5.18 & $(0.02-10.37)$ & 112 & $(011-235)$ & $\begin{array}{r}2.5 \\
100\end{array}$ & $\begin{array}{c}\text { hs } \\
\text { hk }\end{array}$ & $\begin{array}{l}\text { = silty } \\
=\text { sand }\end{array}$ \\
\hline 18 & $\begin{array}{l}\text { b ht Mm } \\
\text { a } \mathrm{KHt}\end{array}$ & $\begin{array}{l}33.14 \\
7.09\end{array}$ & $\begin{array}{l}3.0 \\
6.2\end{array}$ & 44.7 & $(6.3-83.2)$ & 11.6 & $(3.2-37.5)$ & 5.46 & $(171-919)$ & 307 & $(2.31-3.831$ & 128 & $(107-149)$ & .28 & $(.07-.48)$ & .44 & $(.27-.60)$ & 3.99 & $(0.66-7.32)$ & 1.12 & $(0,58-180)$ & $\begin{array}{l}10.0 \\
206\end{array}$ & & $=$ clayey \\
\hline 19 & $\begin{array}{l}\text { b } \mathrm{KHt} \\
\text { a } \mathrm{Hk} \mathrm{Mr}\end{array}$ & $\begin{array}{l}4.92 \\
3.72\end{array}$ & $\begin{array}{l}5.6 \\
4.8\end{array}$ & 4.7 & $(0.8-20.2)$ & 5.0 & $(3.2-\quad 6.8)$ & 2.12 & $(0.90-3.32)$ & 1.67 & $(0.30-3.63)$ & 2.35 & $(2.05-8.35)$ & .82 & $(.69-.94)$ & 1.50 & $(1.42-1.58)$ & 2.92 & $(1.61-4.22)$ & 44 & $(30-.58)$ & $\begin{array}{l}20.0 \\
20.0 \\
30.0\end{array}$ & & \\
\hline 20 & $\begin{array}{l}\mathrm{b} \\
\mathrm{a}\end{array}$ & & $\overline{7.0}$ & 5.9 & $(1.1-10$. & & & 年 & $(1.28-2.88)$ & .92 & $(0.49-1.35)$ & 28 & & .46 & $\left(\begin{array}{ll}(.05 & .87)\end{array}\right.$ & .24 & (.24) & .75 & $(.67-\quad .83)$ & & & $\begin{array}{l}30.0 \\
500\end{array}$ & & \\
\hline 21 & $\begin{array}{l}a \\
\text { a } \mathrm{KHt} \\
\text { KHt }\end{array}$ & $\begin{array}{l}3.00 \\
9.85\end{array}$ & $\begin{array}{l}4.2 \\
2.9\end{array}$ & 1.9 & $(1.7-2.1)$ & 56 & $102-11.01$ & 4.04 & $(2.65-5.43)$ & & & 65 & $(0.21-1.10)$ & 10 & $(08-10)$ & 10 & $(06-14)$ & 53 & $603-1081$ & 1.37 & $(1.13-1.61)$ & 3.0 30 & & \\
\hline 22 & $\begin{array}{l}\text { a KHt } \\
\text { a KHt }\end{array}$ & $\begin{array}{l}4.55 \\
6.50\end{array}$ & $\begin{array}{l}4.6 \\
5.9\end{array}$ & $\begin{array}{l}5.4 \\
3.5\end{array}$ & $\left.\begin{array}{ll}(3.2- & 7.6) \\
(3.3- & 3.7\end{array}\right)$ & & & $\begin{array}{l}11.56 \\
1.67\end{array}$ & $\left(\begin{array}{c}3.36-26.48) \\
(-)\end{array}\right)$ & & - & .72 & $(0.16-1.59)$ & & & & & & & $\begin{array}{l}.78 \\
63\end{array}$ & $(0.08-$ & $\begin{array}{r}5.0 \\
500\end{array}$ & & \\
\hline 26 & $\begin{array}{l}\text { a hk KHt } \\
\text { h h KH+ }\end{array}$ & $\begin{array}{r}5.02 \\
4.14\end{array}$ & 4.8 & 15.4 & $(13.4-17.4)$ & 30 & & 8.33 & $(3.43-13.23)$ & & & .44 & $(.15-\quad .72)$ & & & & & 00 & & 1.21 & $(1.05-$ & 1.5. & & \\
\hline 25 & 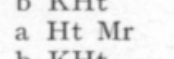 & 5.02 & 4.6 & 14.6 & $(4.9-24.3)$ & 30. & $(2.4-5.3)$ & 27.42 & $(16,54-71.38)$ & & - & .82 & $(0.43-2.06)$ & & & $m$ & $\ln ^{-1}$ & 99 & $(0.27-1.70)$ & 1.16 & $(0.15-2.16)$ & 5.0 & & \\
\hline $\begin{array}{l}27 \\
29\end{array}$ & $\begin{array}{l}\text { a Ht Mr } \\
\text { a }-\end{array}$ & 8.39 & $\begin{array}{l}4.8 \\
5.9\end{array}$ & $\begin{array}{l}7.1 \\
6.9\end{array}$ & 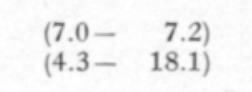 & & & $\begin{array}{r}2.18 \\
.54\end{array}$ & $\left(\begin{array}{l}(1.19- \\
(.40- \\
-.168)\end{array}\right)$ & .57 & $(0.07-1.06)$ & .30 & $\begin{array}{ll}(.24- & .36) \\
(.21- & .49)\end{array}$ & & & .09 & $(.06-.11)$ & .69 & & 1.13 & $(-)$ & $\begin{array}{c}2.0 \\
2.0 \\
\text { Tausta-alue }\end{array}$ & & \\
\hline $\begin{array}{l}30 \\
31\end{array}$ & $\underset{\mathrm{a} \mathrm{Ht}}{\mathrm{Ht}} \overrightarrow{\mathrm{Mr}}$ & 7.40 & 5.1 & $\begin{array}{l}4.5 \\
3.7\end{array}$ & $\left.\begin{array}{ll}(4.1- & 4.9\end{array}\right)$ & & & $\begin{array}{r}.65 \\
1.09\end{array}$ & 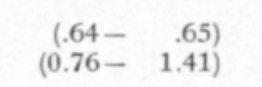 & .81 & $(.77-.85)$ & $\begin{array}{l}.39 \\
.80\end{array}$ & $\begin{array}{r}(.28-.49) \\
(0.06-1.53)\end{array}$ & & & & & & & .79 & $(0.11-1.69)$ & 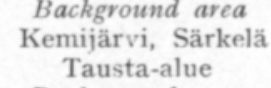 & & \\
\hline 32 & $\begin{array}{l}\text { b ht Mm } \\
\text { a H Ht }\end{array}$ & $\begin{array}{r}26.43 \\
6.01\end{array}$ & $\begin{array}{l}3.4 \\
5.4\end{array}$ & 4.7 & $(4.0-\quad 5.3)$ & 2.9 & $(2.1-\quad 3.7)$ & 3.58 & $(0.83-7.99)$ & & & .35 & $(.23-.47)$ & .17 & $(.16-.17)$ & .16 & $(.11-.20)$ & 1.90 & $(0.68-4.47)$ & 43 & $(.12-.73)$ & : & & \\
\hline 43 & $\begin{array}{l}\mathrm{bH}+\mathrm{Ht} \\
\mathrm{a}^{-}-\mathrm{H}^{-}\end{array}$ & 17. & $\frac{3.2}{6 .}$ & $\begin{array}{r}6.8 \\
0907\end{array}$ & $\begin{array}{r}(2.7-10.8) \\
(4128-1586.5)\end{array}$ & 8.7 & & $\begin{array}{l}1.11 \\
5.50\end{array}$ & $\begin{array}{l}(0.52-1.70) \\
(3.30-14.29)\end{array}$ & & & & & & & .14 & $(.65-.22)$ & .38 & $(.02-$ & & & 10.0 & & \\
\hline 45 & $\begin{array}{l}\text { a Ht Mr } \\
\text { a He Mt } \\
\text { b hk Kh }\end{array}$ & $\begin{aligned} 6.83 \\
44.50\end{aligned}$ & $\begin{array}{l}4.8 \\
2.9\end{array}$ & 9.3 & $(7.9-10.8)$ & 16.5 & $(3.8-29.1)$ & 2.91 & $(-1)$ & & & 1.74 & $(0.90-4.37)$ & 21 & 612 & .10 & $(.03-.17)$ & 49 & $(.30-\quad .67)$ & & & $\begin{array}{l}150 \\
150\end{array}$ & & \\
\hline 46 & 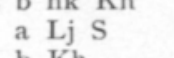 & $\begin{array}{l}7.77 \\
6870 \\
6870\end{array}$ & 年.5. & 7.8 & $(4.7-20.3)$ & 10.0 & $(0.0-2-2.15)$ & 1.44 & $(1.15-1.72)$ & & & .09 & $(-)$ & & & .10 & $1.00-.16$ & & & & & 0.5 & & \\
\hline 47 & 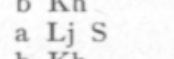 & $\begin{array}{l}6.95 \\
5.95\end{array}$ & $\begin{array}{l}3.8 \\
4.8\end{array}$ & 21.0 & $(18.1-23.8)$ & 104 & $1-$ & .89 & $(0.40-1.37)$ & & & .11 & $(.10-.11)$ & 15 & 1 & . & ${ }^{-1}$ & & & & & $\begin{array}{l}2.0 \\
3.0 \\
3.0\end{array}$ & & \\
\hline 48 & $\begin{array}{l}\text { a Ht } \mathrm{Mr} \\
\text { a H }\end{array}$ & $\begin{array}{l}6.43 \\
5.43 \\
5.45\end{array}$ & 4.9 & 13.5 & $(11.4-15.5)$ & 84.4 & $(7+3-9+4)$ & .31 & $(.22-.39)$ & & & .08 & $(.02-.14)$ & .15 & ${ }^{1-1}$ & & & & & & & $\begin{array}{l}3.0 \\
\text { Tausta-alue }\end{array}$ & & \\
\hline 49 & a $\mathrm{KHt}$ & 5.54 & 6.7 & 3.4 & (3.4) & 1.0 & $0.1=$ & 3.86 & $(3.20-10.92)$ & & & .22 & $(.02-.47)$ & .14 & $\left(\begin{array}{ll}1-1 \\
-1-17\end{array}\right.$ & 07 & $(06-07)$ & 36 & 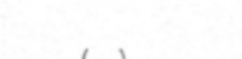 & & & $\begin{array}{l}\text { Backround area } \\
1.0\end{array}$ & & \\
\hline 50 & $\begin{array}{l}\text { b hk KHt } \\
\text { a HHt }\end{array}$ & $\begin{array}{l}14.99 \\
{ }_{4.92}\end{array}$ & 5.2 & 6.9 & $(4.8-8.9)$ & 19.1 & $(-1)$ & .31 & (.31) & & & .15 & $(.08-.21)$ & .13 & . & .07 & - - & . 00 & & & & $\begin{array}{l}1.0 \\
5.0\end{array}$ & & \\
\hline 51 & $\begin{array}{l}\text { b Ht Mr } \\
\text { a KHt }\end{array}$ & $\begin{array}{c}12 . \\
2 .\end{array}$ & $3.8 \mathrm{~S}-\mathrm{s}$ & 2.5 & $(2.1-\quad 2.9)$ & 13.7 & & .15 & $(-)$ & & & . .07 & $(07)$ & .08 & $(.07-.08)$ & .07 & $(.07)$ & .18 & $(-)$ & & & $\begin{array}{l}5.0 \\
\text { sta-alue }\end{array}$ & & \\
\hline 52 & $\begin{array}{l}\text { b } \mathrm{HH}^{-} \mathrm{Mr} \\
\mathrm{b} H \mathrm{HH}\end{array}$ & $\begin{array}{l}227 \\
2097\end{array}$ & $\begin{array}{l}4.2 \\
30\end{array}$ & 4.8 & $(2.7-\quad 6.8)$ & 75 & $(07-156)$ & 42 & $(.05-$ & & & & & .09 & $\begin{array}{l}(.09) \\
(08+099\end{array}$ & .14 & $(.03-.30)$ & & & & & $\begin{array}{l}\text { ackground area } \\
0.1\end{array}$ & & \\
\hline
\end{tabular}




\begin{tabular}{|c|c|c|c|c|c|c|c|c|c|c|c|c|c|c|c|c|c|c|c|}
\hline $\begin{array}{c}\text { Koeala } \\
\text { Plot } \\
\text { No }\end{array}$ & $\begin{array}{c}\text { Paikkakunta } \\
\text { Locality }\end{array}$ & \multicolumn{2}{|c|}{$\begin{array}{l}\text { Viljelymaa } \\
\text { Cultivated soil } \\
\overline{\mathbf{x}}\end{array}$} & \multicolumn{2}{|c|}{$\begin{array}{r}\text { Metsämaa } \\
\text { Forest soil } \\
\overline{\mathrm{x}}\end{array}$} & \multicolumn{2}{|c|}{$\begin{array}{l}\text { Salaatti } \\
\quad \text { Lettuce } \\
\overline{\mathrm{x}} \quad\end{array}$} & \multicolumn{2}{|c|}{$\begin{array}{ll} & \text { Pinaatti } \\
& \text { Spinach } \\
\overline{\mathbf{x}} & \text { Sin }\end{array}$} & \multicolumn{2}{|c|}{$\begin{array}{c}\text { Porkkana } \\
\text { Carrot }\end{array}$} & \multicolumn{2}{|c|}{$\begin{array}{c}\text { Puolukka } \\
\text { Lingonberries } \\
\overline{\bar{x}}\end{array}$} & \multicolumn{2}{|c|}{$\begin{array}{r}\text { Mustikka } \\
\text { Blueberries } \\
\overline{\mathrm{x}}\end{array}$} & \multicolumn{2}{|c|}{$\begin{array}{c}\text { Sienet } \\
\text { Mushrooms } \\
\overline{\mathbf{x}}\end{array}$} & \multicolumn{2}{|c|}{ 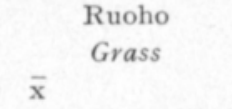 } \\
\hline 1 & Helsinki & 21.1 & $(12.7-29.3)$ & & & 12.1 & $(4.1-20.0)$ & 14.6 & $(7.4-36.6)$ & 4.9 & $(3.2-6.7)$ & & & & & & & & \\
\hline 2 & Tikkurila & 19.1 & $(17.4-20.7)$ & & & 13.0 & $(12.4-13.6)$ & 6.0 & $(-)$ & 4.0 & $(1.1-6.8)$ & & & & & 17.1 & $(-)$ & & \\
\hline 3 & Tikkurila & 29.5 & $(22.3-36.6)$ & & & 32.5 & $(-)$ & & & 5.8 & $(5.7-5.9)$ & & & & & & & & \\
\hline 4 & Tikkurila & 22.0 & $(20.2-23.8)$ & & & 40.8 & $(-)$ & 13.8 & $(-)$ & 5.8 & $(5.8)$ & & & & & & & & \\
\hline 5 & Tikkurila & 37.3 & $(30.5-44.0)$ & & & 28.0 & $(2.8-53.1)$ & 11.0 & $(8.3-13.6)$ & 4.1 & $(3.4-4.7)$ & & & & & & & & \\
\hline 6 & Tikkurila & 47.6 & $(46.2-49.0)$ & & & 25.3 & $(24.2-26.3)$ & 10.8 & (10.8) & 6.9 & $(4.8-8.9)$ & & & & & 16.2 & $(-)$ & 11.2 & $(7.9-14.5)$ \\
\hline 8 & Pertunmaa & 17.7 & $(12.7-22.7)$ & 2.1 & $(1.3-2.9)$ & 5.5 & $(-)$ & & & 4.0 & $(2.9-4.9)$ & 5.4 & $(-)$ & & & 42.1 & $(1.2-82.9)$ & 5.4 & $(4.6-6.2)$ \\
\hline 9 & Punkasalmi & 12.1 & $(8.6-15.4)$ & 3.8 & $(2.0-9.5)$ & 6.6 & $(1.7-11.4)$ & 8.7 & $(6.4-11.1)$ & 2.3 & $(2.3)$ & & & & & & & & \\
\hline 10 & Puumala & 16.0 & $(14.5-17.4)$ & & & 12.2 & $(9.3-15.1)$ & 7.3 & $(6.2-8.3)$ & 4.1 & $(2.7-5.4)$ & & & & & & & & \\
\hline 11 & Tampere & 47.8 & $(41.1-54.5)$ & & & 8.7 & $(1.4-13.2)$ & 11.7 & $(11.6-11.8)$ & 2.9 & $(2.2-3.5)$ & & & & & & & & \\
\hline 12 & Tampere & 28.3 & $(27.0-29.5)$ & & & 6.9 & $(2.4-11.4)$ & 9.9 & $(5.1-14.9)$ & 3.1 & $(2.3-3.9)$ & & & & & & & & \\
\hline 13 & Säynäjärvi & 28.7 & $(25.6-31.7)$ & & & 6.2 & $(4.9-7.4)$ & 12.8 & $(10.1-15.5)$ & 3.3 & (3.3) & 5.4 & $(-)$ & & & & & & \\
\hline 14 & Orivesi & 23.4 & $(19.9-26.8)$ & & & 6.0 & $(5.0-7.0)$ & 10.3 & $(9.6-10.9)$ & & & & & & & & & & \\
\hline 16 & Oulu & 69.9 & $(59.9-79.9)$ & 12.5 & $(6.2-18.8)$ & 10.4 & $(6.9-13.9)$ & 7.1 & $(6.3-7.9)$ & 5.0 & $(3.8-6.2)$ & 5.6 & $(4.8-6.3)$ & 8.8 & $(6.3-11.2)$ & 30.5 & $(21.5-39.4)$ & 15.0( & $(13.3-16.6)$ \\
\hline 17 & Oulu & 10.3 & $(6.5-14.0)$ & 3.5 & $(0.4-7.3)$ & 9.1 & $(7.9-10.4)$ & 9.8 & $(8.8-10.8)$ & 4.4 & $(3.5-5.2)$ & 5.7 & $(3.6-7.7)$ & 6.8 & $(5.6-8.0)$ & 25.2 & $(17.7-32.7)$ & 5.3 & $(3.2-7.3)$ \\
\hline 18 & Haukipudas & 13.4 & $(10.1-16.5)$ & 5.9 & $(1.0-10.8)$ & 5.5 & $(5.1-5.9)$ & 8.3 & $(1.5-18.0)$ & 4.0 & $(2.7-5.4)$ & 4.4 & $(4.0-4.8)$ & 8.3 & $(5.2-11.4)$ & 37.9 & $(22.3-53.4)$ & 6.6 & $(5.9-7.2)$ \\
\hline 19 & $\mathrm{Ii}$ & 7.3 & $(5.8-8.7)$ & & & 10.2 & $(5.4-14.8)$ & 5.6 & $(1.1-10.1)$ & 4.3 & $(2.8-5.7)$ & 5.5 & $(5.3-5.7)$ & 7.5 & (7.5) & 25.0 & $(24.9-25.1)$ & 7.3 & $(5.2-9.3)$ \\
\hline 20 & Olhava & 24.7 & $(2.4-51.8)$ & & & 5.5 & $(4.9-6.1)$ & 5.8 & (5.8) & 2.2 & $(1.3-3.0)$ & & & & & & & 5.4 & (5.4) \\
\hline 21 & Kokkola & 4.6 & $(0.5-8.7)$ & 8.0 & $(2.3-13.7)$ & 12.9 & $(11.3-14.5)$ & & & 7.1 & $(4.6-9.5)$ & & & & & & & 4.3 & $(3.6-4.9)$ \\
\hline 22 & Kokkola & 4.7 & $(2.2-7.1)$ & & & 13.9 & $(6.8-21.0)$ & & & 5.6 & $(5.3-5.8)$ & & & & & & & 8.4 & $(7.6-9.2)$ \\
\hline 23 & Lohtaja & 4.6 & $(0.5-8.7)$ & & & 10.8 & $(-)$ & & & & & & & & & & & & \\
\hline 26 & Kokkola & 8.9 & $(6.4-11.3)$ & 4.6 & $(0.5-8.7)$ & 9.8 & $(2.9-22.5)$ & & & 5.9 & $(5.8-6.0)$ & & & & & & & 11.4 & $(8.3-14.4)$ \\
\hline 25 & Kaarlela & 7.6 & $(5.9-9.2)$ & & & 10.5 & $(2.3-18.6)$ & & & 4.2 & $(2.5-5.8)$ & & & & & & & 4.9 & $(3.6-6.1)$ \\
\hline 27 & Kaustinen & 15.2 & $(6.8-23.5)$ & & & 7.3 & $(1.1-16.7)$ & & & 4.3 & $(-)$ & & & & & & & 7.9 & $(-)$ \\
\hline 29 & Salla & 12.4 & $(8.7-16.0)$ & & & 8.5 & $(5.6-11.4)$ & 4.7 & $(3.7-5.7)$ & 2.8 & $(1.9-3.6)$ & & & & & & & & \\
\hline 30 & Kemijärvi & 19.0 & $(10.0-28.0)$ & & & 4.6 & $(3.9-5.2)$ & 2.1 & $(1.3-2.9)$ & 3.3 & $(1.8-4.7)$ & & & & & & & & \\
\hline 31 & Inari & 15.9 & $(11.0-20.7)$ & 4.3 & $(1.5-7.0)$ & 14.4 & $(9.9-18.9)$ & & & 4.7 & $(3.7-5.7)$ & 6.5 & $(6.1-6.9)$ & 5.5 & $(4.3-6.7)$ & 21.4 & $(15.8-26.7)$ & 9.1 & $(7.6-10.5)$ \\
\hline 32 & Ilomantsi & 9.1 & $(7.8-10.3)$ & & & 8.7 & $(6.1-11.3)$ & 6.6 & $(0.2-12.9)$ & 4.1 & $(2.9-5.2)$ & 5.7 & $(-)$ & & & 24.2 & $(-)$ & 8.2 & $(6.1-10.2)$ \\
\hline 45 & Rovaniemi mlk & 13.4 & $(-)$ & & & 7.1 & $(5.4-8.7)$ & & & 5.5 & $(4.0-6.9)$ & 4.9 & $(-)$ & 5.4 & $(-)$ & & & 9.6 & $(8.8-10.4)$ \\
\hline 46 & Raisio & 22.0 & $(17.5-26.4)$ & 12.8 & $(-)$ & 16.7 & $(12.4-21.0)$ & & & 6.7 & $(-)$ & & & & & & & & \\
\hline 47 & Raisio & 32.6 & $(25.2-40.1)$ & 11.1 & $(6.6-15.6)$ & 15.8 & $(15.5-16.0)$ & & & 8.0 & $(7.6-8.4)$ & 5.3 & $(-)$ & 7.1 & $(-)$ & & & & \\
\hline 48 & Saarijärvi & 11.0 & $(7.3-14.6)$ & 2.4 & $(0.7-4.0)$ & 8.7 & $(7.7-9.7)$ & & & 6.9 & $(6.5-7.3)$ & 4.8 & $(-)$ & & & & & & \\
\hline 49 & Outokumpu & 26.7 & $(22.6-30.8)$ & 106.3 & $(-)$ & 16.1 & $(12.9-19.2)$ & & & 3.4 & $(2.3-4.4)$ & 6.2 & $(5.2-7.2)$ & 6.4 & $(5.0-7.8)$ & 159.2 & $(-)$ & & \\
\hline 50 & Outokumpu & 14.1 & $(13.4-14.7)$ & 25.9 & $(-)$ & 15.1 & $(11.2-18.9)$ & & & 8.2 & $(8.2)$ & 5.0 & $(2.9-7.0)$ & 5.2 & $(1.3-9.0)$ & 110.6 & $(-)$ & & \\
\hline 51 & Maaninka & 8.5 & $(7.2-9.7)$ & & & 7.4 & $(-)$ & & & 5.2 & $(4.1-6.2)$ & 3.7 & $(1.2-6.1)$ & 4.3 & $(0.0-8.5)$ & & & & \\
\hline 52 & Maaninka & 28.8 & $(28.7-28.9)$ & 6.3 & $(4.3-8.3)$ & 11.3 & (11.3) & & & & & 3.0 & $(2.1-3.8)$ & 5.7 & $(-)$ & & & & \\
\hline
\end{tabular}

Liite 2. Kadmiumpitoisuudet man- ja kasvinäytteissä v. 1974-1976, mg/kg k-a. Maalajit liitteessä 1 .

Appendix 2. Cadmium contents on soil and crop samples in 1974-1976, mg/kg d.m. Soil types, see appendix 1.

\begin{tabular}{|c|c|c|c|c|c|c|c|c|c|c|c|c|c|c|c|c|c|}
\hline $\begin{array}{l}\text { Koeala } \\
\text { Plot } \\
\text { No. }\end{array}$ & $\begin{array}{l}\text { Paikkakunta } \\
\text { Locality }\end{array}$ & $\begin{array}{c}\text { Koepaikka } \\
\text { Test site }\end{array}$ & $\begin{array}{l}\text { Viljelymaa } \\
\text { Cultivated soil } \\
\overline{\mathbf{x}}\end{array}$ & & $\begin{array}{l}\text { Tetsämaa } \\
\text { Frest soil }\end{array}$ & $\overline{\mathbf{x}}$ & $\begin{array}{l}\text { Salaatti } \\
\text { Lettuce }\end{array}$ & $\overrightarrow{\mathbf{x}}^{\mathrm{I}}$ & $\begin{array}{l}\text { Pinaatti } \\
\text { Spinach }\end{array}$ & $\begin{array}{l}\text { Porkkana } \\
\text { Carrot } \\
\overline{\mathbf{x}}\end{array}$ & & $\begin{array}{l}\text { aolukka } \\
\text { gonberries }\end{array}$ & $\begin{array}{l}\text { Mustikka } \\
\text { Blueberries } \\
\overline{\mathbf{x}}\end{array}$ & & $\begin{array}{l}\text { Sienet } \\
\text { ushrooms }\end{array}$ & $\begin{array}{l}\text { Laidunruoho } \\
\text { Ley grass } \\
\overline{\mathbf{x}}\end{array}$ & $\begin{array}{c}\text { Etäisyy } \\
\text { Distanc } \\
\text { km }\end{array}$ \\
\hline 1 & Helsinki & Viikki & $.07(.03-.10)$ & & & .30 & $(11 .-.48)$ & .24 & $(07-.54)$ & $.08(.01-.17)$ & & & & & & $.14(.04-.24)$ & 3.0 \\
\hline 2 & Tikkurila & Grönberg & $.08(.03-.12)$ & .41( & $(.15-.56)$ & .75 & $(0.33-1.16)$ & .58 & $(-)$ & $.28(.09-.47)$ & .07 & $(-)$ & $.12(.05-.20)$ & 3.52( & $(0.89-4.51)$ & $.11(.08-.14)$ & 0.2 \\
\hline 3 & Tikkurila & Bera 1 & $.04(.03-.05)$ & .10( & $(.05-.14)$ & 1.00 & $(0.16-2.65)$ & .26 & $(-)$ & $.22(.09-.33)$ & .05 & $(.02-.07)$ & $.18(.05-.30)$ & 1.12( & $(0.52-2.75)$ & $.15(.11-.19)$ & 0.2 \\
\hline 4 & Tikkurila & Bera 2 & $.03(.01-.05)$ & & & .37 & $(-)$ & .30 & $(-)$ & $.17(.08-.42)$ & & & & & & & 0.8 \\
\hline 5 & Tikkurila & Bera 3 & $.03(.02-.03)$ & & & .12 & $(.06-.18)$ & .25 & $(.13-.37)$ & $.10(.02-.18)$ & & & & & & & 1.7 \\
\hline 6 & Tikkurila & Bera 4 & $\begin{array}{ll}.05 & (.05)\end{array}$ & & & .22 & $(.40-.69)$ & .07 & $(.07)$ & $.04 \quad(.40)$ & & & & & & & 2.8 \\
\hline 8 & Pertunmaa & Laukkala & $.05(.02-.09)$ & .09 ( & $(.07-.11)$ & .06 & $(.02-.08)$ & .04 & $(.02-.06)$ & $.06(.02-.08)$ & & & & .70 & $(.43-.97)$ & $.08(.04-.12)$ & $\begin{array}{l}\text { Tausta } \\
\text { Back- } \\
\text { ground }\end{array}$ \\
\hline 9 & Punkasalmi & Sorvasranta & $.05(.01-.09)$ & .04( & $(.02-.06)$ & .48 & $(.15-1.11)$ & & & $.34(.07-.61)$ & .04 & $(.01-.08)$ & $.06(.03-.08)$ & 1.05 & $(.23-1.85)$ & $.05(.02-.07)$ & , \\
\hline 10 & Puumala & Vanhainkoti & $(.02)$ & & & .42 & $(.35-.48)$ & .10 & $.07-.12)$ & $.05(.02-.07)$ & & & & & & & - \\
\hline 11 & Tampere & Messukylä & $.08(.04-.11)$ & & & .38 & $(.11-.65)$ & .18 & $(.04-.40)$ & $.19(.03-.35)$ & & & & & & & 2.0 \\
\hline 12 & Tampere & Aitolahti & $.05(.03-.08)$ & .07 & $(.05-.09)$ & .38 & $(.14-.62)$ & .33 & $20-.45)$ & $.21(.10-.30)$ & .03 & $(.02-.03)$ & .03 (.01-.05) & 1.64 & $(.65-2.62)$ & $.16(.03-.28)$ & 10.0 \\
\hline 13 & Säynäjärvi & Lihasula & $.06(.03-.08)$ & .09( & $(.05-.13)$ & .53 & $(.02-1.07)$ & .50 & $.21-.78)$ & $.29(.06-.52)$ & .05 & $(.02-.08)$ & .06 (.01-.12) & 1.80 & $(.13-3.71)$ & $.17(.07-.27)$ & 20.0 \\
\hline 14 & Orivesi & Somero & $.07(.02-.11)$ & & & .66 & $(.13-1.18)$ & .43 & $.04-.82)$ & $.23(.07-.39)$ & & & & & & $.11(.01-.23)$ & 30.0 \\
\hline 16 & Oulu & Tuira & $.69(.09-1.29)$ & .07( & $(.02-.10)$ & .41 & $(.18-.03)$ & .18 & $.02-.38)$ & $.06(.03-.08)$ & .06 & $(.00-.10)$ & $.13(.08-.17)$ & .56 & $(.32-.79)$ & $.27(.06-.59)$ & 2.0 \\
\hline 17 & Oulu & Kello & $.05(.02-.07)$ & .05 ( & $(.02-.07)$ & .18 & $(.08-.27)$ & .12 & $.05-.18)$ & $.07(.03-.10)$ & .05 & $(.01-.11)$ & $.15(.04-.25)$ & .88 & $(.09-1.65)$ & $.21(.10-.51)$ & 10.0 \\
\hline 18 & Haukipudas & Kauppi & $.13(.07-.17)$ & .05( & $(.04-.08)$ & .96 & $(.49-1.42)$ & .30 & $.20-.79)$ & $.16(.05-.25)$ & .04 & $(.03-.04)$ & $.08(.07-.08)$ & .67 & $(.41-1.75)$ & $.16(.00-.32)$ & 20.0 \\
\hline 19 & $\mathrm{Ii}$ & Paakkola & $.03(.00-.05)$ & & & .26 & $(.07-.44)$ & .10 & $.04-.24)$ & $.18(.02-.36)$ & .11 & $(.01-.23)$ & $.08(.04-.12)$ & .32 & $(.06-.70)$ & (.10) & 30.0 \\
\hline 20 & Olhava & Jakku & $.02(.01-.02)$ & & & .21 & $(.06-.47)$ & .07 & $.02-.11)$ & .03 (.01-.05) & & & & & & & 50.0 \\
\hline 21 & Kokkola & Halkokari & $.04(.02-.04)$ & .07 & $(.01-.13)$ & .83 & $(.03-2.56)$ & .39 & $(-)$ & $.20(.01-.47)$ & .03 & $(.02-.03)$ & $.10(.01-.20)$ & .48 & $(.39-.56)$ & $.20(.11-.28)$ & 3.0 \\
\hline 22 & Kokkola & Friises & $.03(.02-.04)$ & & & .49 & $(.23-1.22)$ & & & $.13(.02-.29)$ & & & & & & $.11(.04-.17)$ & 5.0 \\
\hline 23 & Lohtaja & Sivakkajärvi & $.04(.03-.05)$ & & & .59 & $(.06-.98)$ & .07 & $.01-.15)$ & $\begin{array}{ll}.01 & (.01)\end{array}$ & & & & & & $.08(.06-.10)$ & 10.0 \\
\hline 26 & Kokkola & Ykspihlaja & $.06(.03-.09)$ & .04( & $(.03-.04)$ & .83 & $(.24-1.43)$ & .74 & $.45-1.05)$ & (.08) & & & & & & $.25(.06-.43)$ & 1.5 \\
\hline 25 & Karleby & Sáka & $.04(.01-.07)$ & .01 & $(.01)$ & .47 & $(.11-.81)$ & .32 & $.06-.60)$ & $.17(.05-.29)$ & & & $.05(.03-.07)$ & .44 & $(.17-.70)$ & $.19(.13-.25)$ & 5.0 \\
\hline 27 & Kaustinen & Kattilakoski & $.08(.01-.15)$ & .07 & $(.07)$ & .26 & $(.02-.57)$ & .36 & $(.07-.65)$ & $.26(.04-.48)$ & & & & & & $.07 \quad(-)$ & 20.0 \\
\hline 29 & Salla & Kuusela & $\begin{array}{ll}.01 & (.01)\end{array}$ & & & .19 & $(.08-.45)$ & .10 & $(.04-.24)$ & $.06(.00-.12)$ & & & & & & & $\begin{array}{l}\text { Tausta } \\
\text { Back- } \\
\text { ground }\end{array}$ \\
\hline 31 & Inari & Muddusniem & $.10(.00-.21)$ & .04( & $(.01-.08)$ & .60 & $(.28-1.48)$ & & & $.27(.06-.47)$ & .03 & $(.03)$ & $.06(.02-.10)$ & .55 & $(.36-.73)$ & $.07(.06-.14)$ & , \\
\hline 32 & Nlomantsi & Maat.oppilaitos & $\begin{array}{lll}.07 & (.07)\end{array}$ & .03 & $(.01-.05)$ & .68 & $(.40-1.76)$ & & & $.25 \quad(-)$ & .04 & $(.00-.08)$ & $.04(.01-.06)$ & 1.06 & $(.09-2.03)$ & $.10(.05-.14)$ & - \\
\hline 43 & Kemin mlk & Väyrynen & $.02(.01-.02)$ & & & .16 & $(.00-.32)$ & & & & & & & & & & 10.0 \\
\hline 44 & Helsinki & Viikinmäki & $.55(.06-1.05)$ & & & .12 & $(.07-.13)$ & & & $.05(.00-.09)$ & & & & & & & 0.05 \\
\hline 45 & Rovaniemen mlk & Kalliomäki & $.06(.03-.09)$ & .11 & $(.08-.13)$ & .33 & $(.20-.86)$ & & & $.39(.36-.41)$ & .02 & $(.02)$ & $.03(.02-.04)$ & & & $.17(.03-.31)$ & 15.0 \\
\hline 46 & Raisio & Myllym: & $.05(.03-.07)$ & .04 & $(-)$ & .19 & (.19) & & & $.10 \quad(-)$ & & & $(-)$ & & & & 0.5 \\
\hline 47 & Raisio & Vanhainkoti & $.11 \quad(.11)$ & .16 & $(.14-.18)$ & .66 & $(.64-.68)$ & & & $.12(.07-.16)$ & .06 & $(-)$ & $.07 \quad(-)$ & & & & 3.0 \\
\hline 48 & Saarijärvi & Tarvainen & $.05(.01-.09)$ & .03 & $(.02-.03)$ & .17 & (.17) & & & $.11(.09-.17)$ & .02 & $(-)$ & & & & & $\begin{array}{l}\text { Tausta } \\
\text { Back- } \\
\text { ground }\end{array}$ \\
\hline 49 & Outokumpu & Kovalainer & $.07(.06-.07)$ & .06 & $(-)$ & .09 & $(.06-.11)$ & & & $.05(.01-.11)$ & .02 & $(.00-.04)$ & $.03(.01-.05)$ & 2.21 & $(-)$ & & 1.0 \\
\hline 50 & Outokumpu & Rissanen & $.05(.04-.05)$ & .03 & $(-)$ & .17 & $(.14-.19)$ & & & $.17(.02-.31)$ & .02 & $(.01-.02)$ & $.05(.00-.08)$ & 2.02 & $(-)$ & & 5.0 \\
\hline 51 & Maaninka & Tuovilanlahti & (.04) & & & .07 & $(-)$ & & & $.13(.09-.17)$ & .01 & (.01) & $.06(.04-.08)$ & & & & $\begin{array}{l}\text { Tausta } \\
\text { Back- } \\
\text { ground }\end{array}$ \\
\hline 52 & Maaninka & Sinikivi & $.08(.06-.10)$ & .05 ( & $(.02-.07)$ & .14 & $(.11-.16)$ & & & & .03 & (.03) & $(-)$ & & & & 0.1 \\
\hline
\end{tabular}


Liite 4. Sinkkipitoisuudet maa- ja kasvinåytteissä vv. 1974-1976, mg/kg k-a. Koepaikat ja maalajit liiitteissä 1 ja 2 .

Appendix 4. Zinc contents on soil and crop samples in 1974-1976, in mg/kg d.m. Test sites and soil types, see app. 1 and 2.

\begin{tabular}{|c|c|c|c|c|c|c|c|c|c|c|c|c|c|c|c|c|c|c|}
\hline $\begin{array}{c}\text { Koeala } \\
\text { Plot } \\
\text { No. }\end{array}$ & $\begin{array}{l}\text { Paikkakunta } \\
\text { Locality }\end{array}$ & & 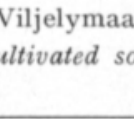 & & & $\begin{array}{l}\text { Metsämaa } \\
\text { Forest soil }\end{array}$ & $\overline{\mathbf{x}}$ & $\begin{array}{l}\text { Salaatti } \\
\text { Lettuce }\end{array}$ & $\begin{array}{r}{ }^{1} \\
\bar{x}\end{array}$ & $\begin{array}{c}\text { Porkkana } \\
\text { Carrot }\end{array}$ & & $\begin{array}{l}\text { 'uolukka } \\
\text { Igonberries }\end{array}$ & & $\begin{array}{l}\text { Mustikka } \\
\text { lueberries }\end{array}$ & $\overline{\mathrm{x}}^{N}$ & $\begin{array}{c}\text { Sienet } \\
\text { Mushrooms }\end{array}$ & $\overline{\mathbf{x}}$ & $\begin{array}{l}\text { Ruoho } \\
\text { Grass }\end{array}$ \\
\hline 1 & Helsinki & 44.1 & (32.1- & 56.1) & 27.0 & $(21.8-32.1)$ & 99.2 & $(76.5-122.0)$ & 37.1 & $(28.1-46.1)$ & & & 9.7 & $(7.9-11.3)$ & 119.0 & $(89.8-148.1)$ & 41.5 & $(34.3-48.6)$ \\
\hline 2 & Tikkurila & 27.2 & $(21.6-$ & 32.7) & 27.1 & $(16.1-38.1)$ & 106.3 & $(89.6-123.0)$ & 65.3 & $(0.7-131.2)$ & 17.8 & $(8.2-27.3)$ & 14.3 & $(9.8-18.7)$ & 107.5 & $(45.7-169.3)$ & 33.1 & $(24.5-41.6)$ \\
\hline 3 & Tikkurila & 50.7 & $(37.4-$ & $64.0)$ & 13.0 & $(12.0-14.0)$ & 153.1 & $(137.0-169.2)$ & 33.8 & $(22.9-44.6)$ & 16.6 & $(16.3-16.8)$ & 17.8 & $(14.7-20.9)$ & 153.2 & $(125.9-180.4)$ & 23.7 & $(20.6-26.8)$ \\
\hline 8 & Pertunmaa & 40.2 & $(26.4-$ & 53.9) & 46.3 & $(44.9-47.7)$ & 55.4 & $(-)$ & 31.5 & $(20.6-42.3)$ & & & & & 98.3 & $(66.0-130.5)$ & 82.1 & $(35.5-128.6)$ \\
\hline 9 & Punkasalmi & 31.3 & $(31.0-$ & $31.5)$ & 13.3 & $(3.6-30.2)$ & 72.5 & $8.6-86$ & 55.5 & $(42.0-68.9)$ & 16.1 & $(9.3-22.8)$ & 12.9 & $(10.0-15.7)$ & 114.3 & $(107.6-120.9)$ & 39.5 & $(28.0-50.9)$ \\
\hline 11 & Tampere & 166.6 & $(115.6-$ & 217.6) & & & 80.2 & $(-)$ & 42.7 & $(18.0-67.4)$ & & & & & & & & \\
\hline 12 & Tampere & 92.7 & $(82.5-$ & 103.0) & 39.8 & $(35.3-44.2)$ & 126.0 & (68.3-183.6) & 49.6 & $(32.1-67.0)$ & 8.5 & $(6.8-10.1)$ & 7.1 & $(4.2-10.0)$ & 103.5 & $(94.3-112.7)$ & 43.7 & $(38.7-48.7)$ \\
\hline 13 & Säynäjärvi & 69.8 & $(65.7-$ & $74.0)$ & 45.0 & $(41.7-48.2)$ & 71.7 & $(38.2-105.2)$ & 30.7 & $(22.3-39.0)$ & 12.3 & $(9.4-15.3)$ & 7.2 & $(6.4-8.0)$ & 107.0 & $(77.3-136.6)$ & 36.4 & $(35.4-37.4)$ \\
\hline 14 & Orivesi & 73.8 & (70.9- & 76.7) & & & 69.4 & $(52.7-86.1)$ & 49.7 & $(20.9-78.4)$ & & & & & & & 42.3 & $(28.6-56.0)$ \\
\hline 16 & Oulu & 918.1 & $(689.4-1$ & (146.7) & 42.7 & $(11.7-73.5)$ & 220.4 & $(193.1-247.6)$ & 35.8 & $(27.6-44.0)$ & 11.30 & $(8.6-13.9)$ & 47.1 & $(31.5-62.6)$ & 148.0 & $(102.1-194.0)$ & 211.6 & $(197.1-226.1)$ \\
\hline 17 & Oulu & 54.2 & $(2.0-$ & 110.3) & 16.7 & $(11.9-21.5)$ & 106.1 & $(62.8-149.2)$ & 32.6 & $(26.7-38.4)$ & 20.0 & $(14.3-25.7)$ & 52.7 & $(5.9-99.5)$ & 130.2 & $(102.4-157.8)$ & 39.3 & $(28.3-50.3)$ \\
\hline 18 & Haukipudas & 142.1 & (79.1 - & 205.1) & 29.7 & $(5.8-53.6)$ & 676.9 & $(614.4-739.4)$ & 118.0 & $(102.5-133.5)$ & 19.1 & $(12.4-25.8)$ & 29.4 & $(28.4-30.4)$ & 117.5 & $(109.1-126.0)$ & 86.8 & $(73.1-100.5)$ \\
\hline 19 & Ii & 22.8 & $(22.5-$ & 23.0) & & & 109.2 & $(80.6-137.7)$ & 48.5 & $(44.0-53.0)$ & 18.1 & $(10.7-25.4)$ & 37.6 & $(32.4-42.7)$ & 89.9 & $(40.1-139.5)$ & 52.3 & $(47.2-57.4)$ \\
\hline 21 & Kokkola & 8.4 & $(-)$ & & 35.1 & $(21.6-91.8)$ & 137.3 & $(123.2-151.4)$ & 41.4 & $(29.5-53.2)$ & 10.7 & $(9.9-11.5)$ & 11.1 & $(10.4-11.7)$ & 98.2 & $(67.1-129.2)$ & 66.8 & $(44.1-89.5)$ \\
\hline 22 & Kokkola & 30.3 & $(16.6-$ & 43.9) & & & 127.7 & $(50.7-204.6)$ & 53.5 & $(41.5-65.5)$ & & & & & & & 45.1 & $(38.0-52.2)$ \\
\hline 23 & Lohtaja & 21.3 & $(20.6-$ & 21.9) & & & 112.0 & $(-)$ & & & & & & & & & 34.7 & $(27.8-41.6)$ \\
\hline 26 & Kokkola & 59.5 & $(36.5-$ & $82.5)$ & 12.9 & $(2.0-23.7)$ & 71.6 & $(37.3-105.9)$ & 64.4 & $(63.3-65.4)$ & & & & & 125.8 & $(122.7-128.8)$ & 114.5 & $(96.9-132.1)$ \\
\hline 25 & Kaarlela & 48.0 & $(11.7-$ & 84.3) & 5.1 & $(4.1-6.1)$ & 128.7 & $(17.1-274.4)$ & 69.5 & $(52.7-86.2)$ & & & 10.2 & $(9.3-11.0)$ & 79.1 & $(70.5-87.6)$ & 78.7 & $(62.3-95.0)$ \\
\hline 27 & Kaustinen & 40.1 & $(29.8-$ & 50.3) & & & 122.9 & $(120.8-124.9)$ & 42.2 & $(21.4-63.0)$ & & & & & & & 61.9 & $(-)$ \\
\hline 31 & Inari & 29.1 & $(27.8-$ & 30.3) & 14.7 & $(4.9-34.3)$ & 42.8 & $(42.0-43.6)$ & 30.8 & $(18.3-43.3)$ & 22.3 & $(20.1-24.5)$ & 14.0 & $(12.3-15.6)$ & 91.3 & $(89.4-93.1)$ & 38.8 & $(29.8-47$ \\
\hline 32 & Ilomantsi & 32.5 & $(31.8-$ & 33.1) & & & 99.0 & $(27.7-170.2)$ & 21.6 & $(15.8-27.3)$ & 14.9 & $(9.7-20.0)$ & & & 113.6 & $(-)$ & 56.7 & $(36.2-7$ \\
\hline $44 \quad 1$ & Helsinki & 1301.3 & $(974.3-1$ & 1628.2) & & & 147.5 & $(138.3-156.7)$ & 32.3 & $(30.8-33.7)$ & & & & & & & & \\
\hline 45 & Rovaniemen mlk & 64.0 & $(42.2-$ & $85.7)$ & 29.9 & $(24.6-35$. & 79.3 & $(76.2-82.3)$ & 42.0 & $(28.1-55.8)$ & 14.9 & $(13.9-15.9)$ & 8.7 & $(4.2-13$. & & & 50.3 & $(41.7-5$ \\
\hline 46 & Raisio & 78.3 & $(74.4-$ & $82.2)$ & 33.6 & $(-)$ & 82.4 & $(76.2-88.5)$ & 24.6 & $(-)$ & & & 17.7 & $(-)$ & & & & \\
\hline 47 & Raisio & 131.0 & $(121.8-$ & 140.1) & 40.9 & $(32.1-49.7)$ & 25.7 & $(23.7-27.7)$ & 20.6 & $(20.2-21.0)$ & 11.5 & $(-)$ & 14.4 & 1 & & & & \\
\hline 48 & Saarijärvi & 41.0 & $(40.4-$ & 41.6) & 18.7 & $(11.3-26.2)$ & 81.3 & $(78.2-84.3)$ & 29.4 & $(26.0-33.0)$ & 9.5 & $(-)$ & & & & & & \\
\hline 49 & Outokumpr & 51.0 & $(49.7-$ & 52.2) & 24.3 & $(-)$ & 36.2 & $(31.7-40.6)$ & 7.4 & $(7.1-7.6)$ & 10.9 & $(7.6-14.2)$ & 9.1 & $0.7)$ & 113.0 & $(-$ & & \\
\hline 50 & Outokumpu & 54.3 & $(43.4-$ & 65.1) & 44.4 & $(-)$ & 89.6 & $(61.8-117.3)$ & 23.2 & $(20.9-25.6)$ & 8.4 & $(7.6-9.2)$ & 9.6 & $(7.7-11.4)$ & 87.3 & $(-)$ & & \\
\hline 51 & Maaninka & 18.8 & $(17.7-$ & 19.8) & & & 33.4 & $(-)$ & 19.9 & $(6.8-32.9)$ & 8.7 & $(8.3-9.1)$ & 8.1 & $(7.0-9.1)$ & & & & \\
\hline 52 & Maaninka & 48.4 & $(39.8-$ & 57.0) & 23.7 & $(21.4-25.9)$ & 75.8 & $(70.1-81.5)$ & & & 8.4 & $(8.3-8.5)$ & 8.3 & $(-)$ & & & & \\
\hline
\end{tabular}

Liite 5. Elohopeapitoisuudet maa- ja kasvinäytteissä v. 1974-1976, mg/kg k-a. Koepaikat ja maalajit liitteissă 1 ja 2.

Appendix 5. Mercury contents in soil and crop samples in 1974-1976, in mg/kg d.m. Test sites and soil types, see app. 1 and 2.

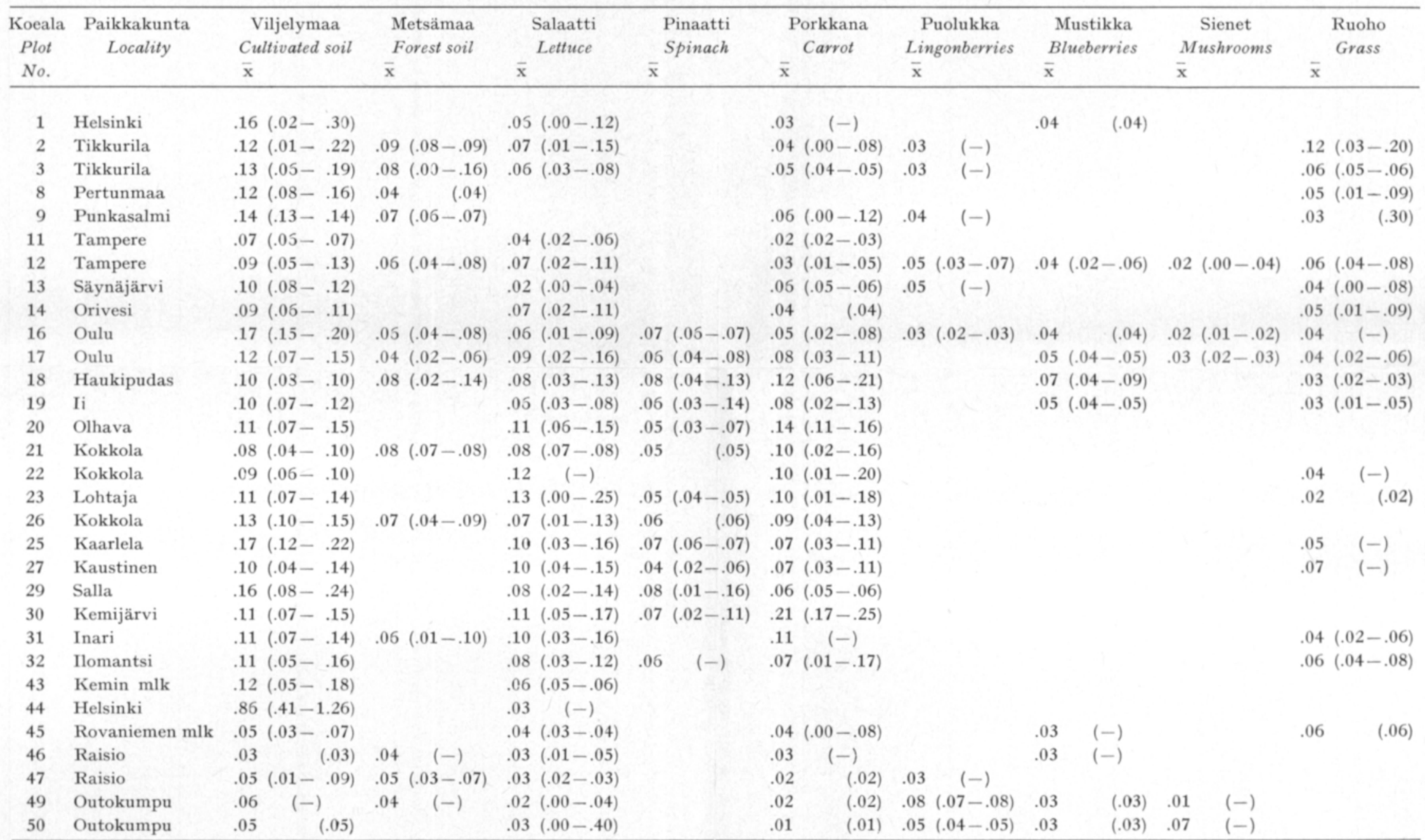

Liite 6. Arseenipitoisuudet maa- ja kasvinäytteissä v. 1974-1976, mg/kg k-a. Paikkakunnat ja maalajit, liitteet 1 ja 2.

\begin{tabular}{|c|c|c|c|c|c|c|c|c|c|c|c|c|c|c|c|c|c|c|c|}
\hline $\begin{array}{c}\text { Koeala } \\
\text { Plot } \\
\text { No. }\end{array}$ & $\begin{array}{l}\text { a Paikkakunta } \\
\text { Locality }\end{array}$ & $\begin{array}{l}\text { Vil } \\
\text { Cult } \\
\overline{\mathbf{x}} \\
\end{array}$ & $\begin{array}{l}\text { ljelymaa } \\
\text { ivated soil }\end{array}$ & & $\begin{array}{l}\text { Metsämaa } \\
\text { Forest soil }\end{array}$ & $\overline{\mathbf{x}}$ & $\begin{array}{l}\text { Salaatti } \\
\text { Lettuce }\end{array}$ & & $\begin{array}{l}\text { Pinaatti } \\
\text { Spinach }\end{array}$ & & $\begin{array}{l}\text { Porkkana } \\
\text { Carrot }\end{array}$ & & $\begin{array}{l}\text { Puolukka } \\
\text { ngonberries }\end{array}$ & & $\begin{array}{l}\text { Mustikka } \\
\text { Blueberries }\end{array}$ & & $\begin{array}{l}\text { Sienet } \\
\text { Iushrooms }\end{array}$ & $\overline{\mathbf{x}}$ & $\begin{array}{l}\text { Ruoho } \\
\text { Grass }\end{array}$ \\
\hline 1 & Helsinki & 2.60 & $(2.40-2.80)$ & & & 0.40 & $(0.19-0.99)$ & & & 0.50 & $(0.30-0.70)$ & & & & & & & & \\
\hline 2 & Tikkurila & 5.65 & $(4.30-7.00)$ & 8.81 & $(2.79-14.82)$ & 1.15 & $(0.27-2.03)$ & & & 0.60 & $(0.40-0.80)$ & 0.30 & $(0.09-0.69)$ & 0.55 & $(0.26-0.84)$ & 0.71 & $(0.03-1.38)$ & 0.80 & $(0.57-2.17)$ \\
\hline 3 & Tikkurila & 2.90 & $(2.90)$ & 1.75 & $(.08-3.42)$ & 1.00 & (1.00) & & & 0.40 & $(0.40)$ & 0.20 & $(0.20)$ & 0.40 & $(0.01-0.79)$ & 0.95 & $(0.46-1.44)$ & 0.25 & $(0.04-0.54)$ \\
\hline 8 & Pertunmaa & 1.90 & $(1.70-2.10)$ & 1.20 & $(0.81-1.59)$ & 1.40 & $(-)$ & & & 0.70 & $(0.50-0.90)$ & & & & & 0.60 & $(0.01-1.19)$ & 0.35 & $(0.14-0.84)$ \\
\hline 9 & Punkasalmi & 1.55 & $(0.62-2.58)$ & 0.65 & $(0.04-1.34)$ & 0.30 & $(0.09-0.69)$ & & & 0.55 & $(0.45-0.65)$ & 0.15 & $(0.05-0.25)$ & 0.40 & $(0.20-0.60)$ & 0.46 & $(0.11-0.81)$ & 0.25 & $(0.04-0.54)$ \\
\hline 11 & Tampere & 2.57 & $(0.51-4.63)$ & & & 0.87 & $(0.62-1.11)$ & & & 0.34 & $(0.15-0.53)$ & & & & & & & & \\
\hline 12 & Tampere & 3.43 & $(3.05-3.81)$ & 1.81 & $(1.52-2.10)$ & 0.28 & $(0.08-0.46)$ & & & 0.58 & $(0.33-0.82)$ & 0.29 & $(0.15-0.43)$ & 0.36 & $(0.35-0.36)$ & 0.24 & $(0.13-0.61)$ & 0.60 & $(0.40-0.80)$ \\
\hline 13 & Säynäjärvi & 2.33 & $(1.84-2.82)$ & 1.06 & $(0.08-2.04)$ & 1.65 & $(0.77-2.53)$ & & & 0.50 & $(0.11-0.89)$ & 0.28 & $(0.15-0.35)$ & 0.56 & $(0.29-0.83)$ & 0.61 & $(0.19-1.02)$ & 0.35 & $(0.25-0.45)$ \\
\hline 14 & Orivesi & 2.05 & $(1.77-3.87)$ & 2.05 & $(1.58-3.68)$ & & & & & 0.40 & $(0.40)$ & & & & & & & 1.10 & $(0.27-2.47)$ \\
\hline 16 & Oulu & 10.80 & $(-)$ & 0.81 & $(0.45-1.17)$ & 1.46 & $(0.18-2.73)$ & & & 0.77 & $(0.37-1.15)$ & 0.21 & $(0.12-0.27)$ & 0.55 & $(0.45-0.65)$ & 0.95 & $(0.40-1.48)$ & 1.70 & $(1.11-2.29)$ \\
\hline 17 & Oulu & 0.74 & $(0.60-0.87)$ & 0.62 & $(0.23-1.01)$ & 2.68 & $(0.92-7.26)$ & & & 0.33 & $(0.13-0.52)$ & 0.25 & $(0.15-0.35)$ & 0.35 & $(0.25-0.45)$ & 0.37 & $(0.06-0.67)$ & 0.20 & $(0.19-0.59)$ \\
\hline 18 & Haukipudas & 1.55 & $(1.26-1.84)$ & 2.20 & $(0.54-4.94)$ & 1.00 & $(0.61-1.39)$ & & & 1.10 & $(0.32-1.88)$ & 0.15 & $(0.05-0.25)$ & 0.45 & $(0.04-0.94)$ & 0.20 & $(0.20)$ & 0.30 & $(0.10-0.50)$ \\
\hline 19 & Ii & 0.75 & $(0.46-1.04)$ & & & 0.60 & $(0.40-0.80)$ & & & 1.00 & $(0.80-1.20)$ & 0.25 & $(0.15-0.35)$ & 0.35 & $(0.25-0.45)$ & 0.30 & $(0.30)$ & 0.20 & $(0.19-0.59)$ \\
\hline 21 & Kokkola & 1.55 & $(0.49-2.61)$ & 0.93 & $(0.52-1.34)$ & 1.08 & $(0.16-1.99)$ & 0.95 & $(0.07-1.83)$ & 0.38 & $(0.20-0.67)$ & 0.18 & $(0.15-0.20)$ & 0.35 & $(0.29-0.41)$ & 0.38 & $(0.32-0.44)$ & 0.20 & $(0.20)$ \\
\hline 22 & Kokkola & 1.53 & $(0.14-2.91)$ & & & 1.05 & $(0.08-1.72)$ & & & 2.90 & $(1.76-7.22)$ & & & & & & & 0.30 & $(0.30)$ \\
\hline 23 & Lohtaja & 1.58 & $(0.68-2.47)$ & & & 0.07 & $(0.00-0.13)$ & 0.99 & $(0.26-1.64)$ & 0.95 & $(0.13-2.03)$ & & & & & & & 0.35 & $(0.25-0.45)$ \\
\hline 26 & Kokkola & 1.99 & $(1.49-2.49)$ & 1.89 & $(0.42-3.36)$ & 1.58 & $(1.04-2.11)$ & 1.50 & $(0.91-2.09)$ & 0.40 & $(0.14-1.11)$ & & & & & 0.64 & $(0.37-0.90)$ & 0.20 & $(0.00-0.40)$ \\
\hline 25 & Kaarlela & 2.03 & $(1.62-2.44)$ & 0.51 & $(0.38-0.64)$ & 0.82 & $(0.06-3.09)$ & 1.25 & $(0.42-2.92)$ & 0.48 & $(0.26-1.21)$ & 0.27 & $(-)$ & 0.47 & $(0.06-0.87)$ & 0.44 & $(0.27-0.60)$ & 0.10 & \\
\hline 27 & Kaustinen & 3.40 & $(1.40-5.40)$ & 0.88 & $(0.43-1.33)$ & 0.18 & $(0.05-0.55)$ & 1.75 & $(1.46-2.04)$ & 0.60 & $(0.27-0.93)$ & & & & & & & 0.40 & $(-)$ \\
\hline 31 & Inari & 0.95 & $(0.66-1.24)$ & 0.80 & $(0.17-2.17)$ & 0.70 & $(0.48-1.88)$ & & & 1.20 & $(0.76-3.16)$ & 0.15 & $(0.05-0.25)$ & 0.40 & $(0.19-0.99)$ & 0.25 & $(0.04-0.54)$ & 0.15 & $(0.05-0.2$ \\
\hline 32 & Ilomantsi & 0.95 & $(0.52-1.42)$ & 0.56 & $(0.46-0.66)$ & 0.35 & $(0.06-0.64)$ & & & 0.75 & $(0.33-1.83)$ & 0.20 & $(0.20)$ & 0.54 & $(0.27-0.81)$ & 0.66 & $(0.17-1.49)$ & 0.30 & $(0.09-0.64)$ \\
\hline 44 & Helsinki & 5.70 & $(3.40-7.90)$ & & & 0.20 & $(-)$ & & & & & & & & & & & & \\
\hline 45 & Rovaniemen mlk & 2.05 & $(0.97-3.13)$ & & & 0.20 & $(0.20)$ & & & 0.60 & $(0.01-1.19)$ & 0.25 & $(0.15-0.35)$ & 0.20 & $(-)$ & & & 0.20 & $(0.2$ \\
\hline 46 & Raisio & 1.55 & $(0.91-2.18)$ & 3.30 & 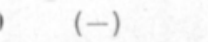 & 0.18 & $(0.18)$ & & & 0.31 & $(-1)$ & & & 0.42 & $(-)$ & & & & \\
\hline 47 & Raisio & 2.20 & $(0.19-4.58)$ & 1.17 & $(0.99-1.35)$ & 0.28 & $(0.21-0.34)$ & & & 0.18 & $(0.15-0.20)$ & 0.23 & $(-)$ & 0.43 & $(-)$ & & & & \\
\hline 48 & Saarijär & 0.47 & $(0.43-0.51)$ & 0.53 & $(0.28-0.77)$ & 0.90 & $(0.59-1.2)$ & & & 0.18 & $(0.11-0.24)$ & 0.50 & $(-)$ & & & & & & \\
\hline 49 & Outokumpu & 1.10 & $(0.28-1.92)$ & 1.19 & $(-)$ & 0.67 & $(0.54-0.79)$ & & & 0.09 & $(0.05-0.23)$ & 0.23 & $(0.13-0.33)$ & 0.61 & $(0.34-0.88)$ & 0.49 & $(-)$ & & \\
\hline 50 & Outokumpu & 0.78 & $(0.22-1.33)$ & 1.31 & $(1.21-1.41)$ & 0.45 & $(0.40-0.49)$ & & & 0.21 & $-0.31)$ & 0.62 & $(0.01-1.25)$ & 0.48 & $(0.29-0.66)$ & 0.43 & $(-)$ & & \\
\hline 51 & Maaninka & 1.02 & $(0.69-1.35)$ & & & 0.11 & $(-)$ & & & 0.23 & $(0.18-0.27)$ & 0.22 & $(0.11-0.32)$ & 0.33 & $(0.19-0.47)$ & & & & \\
\hline 52 & Maaninka & 1.36 & $(0.78-1.93)$ & 0.51 & $(0.40-0.61)$ & 0.51 & $(0.21-1.22)$ & & & & & 0.42 & $(0.15-0.69)$ & 0.54 & $(-)$ & & & & \\
\hline
\end{tabular}


Liite 7. Rikkipitoisuudet maa- ja kasvinäytteissä v, 1974-1976, g/kg k-a. Paikkakunnat ja maalajit, liitteet 1 ja 2 .

Appendix 7. Sulphur contents in soil and crop samples in 1974-1976, in g/kg d.m. Test sites and soil types, see app. 1 and 2.

\begin{tabular}{|c|c|c|c|c|c|c|c|c|c|c|c|c|c|c|c|c|c|c|c|}
\hline $\begin{array}{c}\text { Koeala } \\
\text { Plot } \\
\text { No. } \\
\end{array}$ & $\begin{array}{l}\text { Paikkakunta } \\
\text { Locality }\end{array}$ & \multicolumn{2}{|c|}{$\begin{array}{l}\text { Viljelymaa } \\
\text { Cultivated soil } \\
\overline{\mathrm{x}}\end{array}$} & \multicolumn{2}{|c|}{$\begin{array}{l}\text { Metsämaa } \\
\text { Forest soil } \\
\overline{\mathbf{x}}\end{array}$} & \multicolumn{2}{|c|}{$\begin{aligned} & \text { Salaatti } \\
& \text { Lettuce } \\
\overline{\mathbf{x}} & \end{aligned}$} & \multicolumn{2}{|c|}{$\begin{array}{l}\text { Pinaatti } \\
\text { Spinach } \\
\mathrm{x}\end{array}$} & \multicolumn{2}{|r|}{$\begin{array}{c}\text { Porkkana } \\
\text { Carrot }\end{array}$} & \multicolumn{2}{|c|}{$\begin{array}{l}\text { Puolukka } \\
\text { Lingonberries } \\
\overline{\mathrm{x}}\end{array}$} & \multicolumn{2}{|c|}{$\begin{array}{l}\text { Mustikka } \\
\text { Blueberries } \\
\overline{\mathbf{x}}\end{array}$} & \multicolumn{2}{|c|}{$\begin{array}{c}\text { Sienet } \\
\text { Mushrooms } \\
\overline{\mathrm{x}}\end{array}$} & \multicolumn{2}{|c|}{ 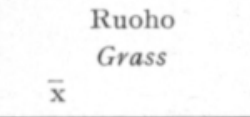 } \\
\hline 1 & Helsinki & .46 & $(.25-.66)$ & & & 2.73 & $(2.37-3.09)$ & 3.31 & $(2.92-3.70)$ & .72 & $(.52-.92)$ & & & & & & & & \\
\hline 2 & Tikkurila & 1.04 & $(0.50-1.57)$ & & & 2.28 & $(1.32-3.23)$ & 3.52 & $(-)$ & .62 & (.62) & & & & & & & & \\
\hline 3 & Tikkurila & .28 & $(.13-.42)$ & & & 2.48 & $(-)$ & 3.11 & $(-)$ & .42 & $(.29-.54)$ & & & & & & & & \\
\hline 4 & Tikkurila & .46 & $(.27-.64)$ & & & 2.00 & $(-)$ & 2.48 & $(-)$ & .59 & $(.24-.93)$ & & & & & & & & \\
\hline 5 & Tikkurila & .25 & $(.04-.45)$ & & & 1.52 & $(1.25-1.79)$ & 2.31 & $(1.98-2.64)$ & .48 & $(.48)$ & & & & & & & & \\
\hline 6 & Tikkurila & .66 & $(.59-.72)$ & & & 2.62 & $(2.35-2.89)$ & 3.90 & $(3.70-4.10)$ & .59 & $(.52-.65)$ & & & & & & & & \\
\hline 8 & Pertunmaa & .65 & $(.32-.98)$ & .63 & $(.42-.83)$ & 1.85 & $(1.38-2.18)$ & 3.04 & $(-)$ & .59 & $(.49-.67)$ & & & & & 1.18 & $(0.91-1.44)$ & 1.51 & $(0.40-2.61)$ \\
\hline 9 & Punkasalmi & .86 & $(.81-.90)$ & .45 & $(.12-.78)$ & 4.11 & $(3.62-4.60)$ & & & .89 & $(.83-.95)$ & .47 & $(-)$ & & & 1.90 & $(1.83-1.96)$ & .98 & $(0.47-1.49)$ \\
\hline 16 & Oulu & .43 & $(.29-.58)$ & 1.29 & $(0.15-2.41)$ & 2.11 & $(1.79-2.43)$ & 4.59 & $(3.03-6.14)$ & .77 & $(0.39-1.15)$ & .88 & $8(0.52-1.24)$ & 1.91 & $(1.31-2.50)$ & 2.15 & $(1.63-2.65)$ & 2.80 & $(2.35-3.25)$ \\
\hline 17 & Oulu & .33 & $(.24-.40)$ & .60 & $(.35-.85)$ & 2.05 & $(1.61-2.49)$ & 2.86 & $(2.25-3.47)$ & 1.03 & $(0.79-1.27)$ & .76 & $5(0.51-1.00)$ & 1.75 & $5(0.89-2.61)$ & 2.33 & $(1.08-3.57)$ & 1.12 & $(0.87-1.36)$ \\
\hline 18 & Haukipudas & .24 & $(.12-.36)$ & .56 & $(.53-.58)$ & 2.04 & $(1.14-2.93)$ & 1.73 & $(0.38-3.08)$ & .78 & $(.62-.93)$ & .50 & $(.46-.54)$ & 1.52 & $2(0.17-2.87)$ & 1.51 & $(1.46-1.55)$ & 1.34 & $(0.99-1.69)$ \\
\hline 19 & $\mathrm{Ii}$ & .29 & $(.03-.45)$ & & & 2.02 & $(1.64-2.40)$ & 2.59 & $(1.30-3.87)$ & .75 & $(.52-.97)$ & .51 & $1 \quad(.44-.57)$ & 1.11 & $(0.02-2.19)$ & 1.47 & $(1.36-1.57)$ & 1.46 & $(1.11-1.80)$ \\
\hline 20 & Olhava & .10 & $(.09-.10)$ & & & 1.17 & $(1.17)$ & 2.93 & $(2.19-3.67)$ & .66 & $(.45-.86)$ & & & & & & & & \\
\hline 29 & Salla & .12 & $(.05-.30)$ & & & 1.14 & $(0.93-1.34)$ & 2.08 & $(1.40-2.75)$ & .87 & $(0.66-1.07)$ & & & & & & & & \\
\hline 30 & Kemijärvi & .23 & $(.29-.37)$ & & & 1.45 & $(1.18-1.72)$ & 2.83 & $(1.75-3.91)$ & .76 & $(.76)$ & & & & & & & & \\
\hline 31 & Inari & .32 & $(.03-.52)$ & .43 & $(.36-.49)$ & 1.00 & $(0.94-1.15)$ & & & .90 & $(-)$ & 1.16 & $5(0.09-2.40)$ & 1.09 & $9(0.03-2.21)$ & 2.04 & $(1.69-2.38)$ & 1.52 & $(1.47-1.56)$ \\
\hline 32 & Ilomantsi & .20 & $(.06-.34)$ & & & 1.83 & $(1.76-1.89)$ & 4.42 & $(1.58-7.25)$ & .62 & $(0.09-1.15)$ & & & & & & & & \\
\hline 43 & Kemin mlk & .18 & $(.11-.24)$ & & & 1.59 & $(1.18-1.99)$ & & & & & & & & & & & & \\
\hline 48 & Saarijärvi & .31 & $(.26-.35)$ & .22 & $(.10-.34)$ & 2.18 & $(2.11-2.24)$ & & & 1.26 & $(1.08-1.44)$ & .93 & $(-)$ & & & & & & \\
\hline 49 & Outokumpu & .40 & $(.26-.54)$ & .48 & $(-)$ & 2.62 & (2.62) & & & 1.42 & $(1.07-1.76)$ & .95 & $(0.58-1.32)$ & 1.35 & $(1.35)$ & 9.38 & $(-)$ & & \\
\hline 50 & Outokumpu & .45 & $(.12-.77)$ & .47 & $(-)$ & 2.24 & $(2.04-2.44)$ & & & 1.38 & $(1.24-1.52)$ & .80 & $(0.59-1.00)$ & 1.11 & $(1.04-1.17)$ & 7.59 & $(-)$ & & \\
\hline 51 & Maaninka & .28 & $(.25-.30)$ & & & 1.81 & $(-)$ & & & 1.07 & $(0.87-1.27)$ & .86 & $(0.39-1.33)$ & 1.18 & $8(0.91-1.44)$ & & & & \\
\hline 52 & Maaninka & .19 & $(.19)$ & .42 & $(.26-.58)$ & 2.43 & $(2.14-2.71)$ & & & & & .90 & $(0.69-1.10)$ & 1.00 & $(-)$ & & & & \\
\hline
\end{tabular}

